Schulich School of Law, Dalhousie University

Schulich Law Scholars

2016

Functional Interactions and Maritime Regulation: The Mutual Accommodation of Offshore Wind Farms and International Navigation and Shipping

Aldo Chircop

Peter L'Esperance

Follow this and additional works at: https://digitalcommons.schulichlaw.dal.ca/scholarly_works

Part of the Environmental Law Commons 
IN PRESS: 30 OCEAN YEARBOOK 439-487 (2016)

\title{
FUNCTIONAL INTERACTIONS AND MARITIME REGULATION THE MUTUAL ACCOMMODATION OF OFFSHORE Wind FARMS AND INTERNATIONAL NAVIGATION AND SHIPPING
}

\begin{abstract}
Aldo Chircop \& Peter L'Esperance
Acknowledgements: The authors acknowledge grant support from: Schulich Academic Excellence Fund at Dalhousie University and Social Sciences and Humanities Research Council of Canada. The authors are grateful for the research assistance of John Hillman, Sir James Dunn Law Library, Schulich School of Law, Dalhousie University, and to Dr. Tullio Scovazzi, Professor of International Law, University of Milano-Bicocca, Milan, Italy, for comments on an earlier version of this article. Feedback from blind reviewers of the Ocean Yearbook is also acknowledged.
\end{abstract}

\section{INTRODUCTION}

There is growing interest in Europe and North America in locating wind farms in ocean space within national jurisdiction. For many States, wind is the renewable energy of choice in the search for alternatives to fossil fuels to meet emissions reductions targets established by international agreement on a large scale. ${ }^{1}$ Locating windfarms in the marine environment is attractive because of the availability of open spaces to accommodate extensive arrays capable of producing power on a large scale, ideal wind conditions and less likelihood of impacts that trigger public opposition, such as noise, lowering of property values and interference with landscape aesthetics. However, offshore windfarms (OWFs) produce a range of spatial and functional impacts on existing marine uses. The spatial footprint includes arrays, associated installations, submarine cable grids and safety zone belts. For safety reasons, the occupied ocean and air space is allocated to the OWF on an exclusive and permanent basis or for very long periods of time. ${ }^{2}$ The allocation may occur at the expense of fishing grounds and existing navigation routes. In particular, densely used marine spaces, such as in the Baltic and North Sea, may necessitate exclusive spatial allocation to minimize the danger of collisions and heightened risk of consequential pollution. ${ }^{3}$ Clearly, the advent and proliferation of OWFs raise concerns among existing ocean users and underscores the

\footnotetext{
${ }^{1}$ For example the recently opened Gwynt y Môr site, off the coast of Wales, has 160 turbines that will generate $576 \mathrm{MW}$ of power, enough to supply 400,000 homes. "World's second largest offshore wind farm opens in Wales," Climate Action, 22 June 2015, available online: <http://www.climateactionprogramme.org/news/worlds_second_largest_offshore_wind_farm_opens_in_wales>.

${ }^{2}$ Even with regards to offshore oil and gas fields, the related installations and structures tend to occupy ocean space for the duration of the installation's economic lifecycle, usually in the region of 25-30 years.

${ }^{3}$ R. Long, "Offshore Wind Energy Development and Ecosystem-Based Marine Management in the EU: Are Regulatory Answers Really Blowing in the Wind?" in The Regulation of Continental Shelf Development: Rethinking International Standards, ed. M.H. Nordquist et al. (Leiden: Martinus Nijhoff, 2013), pp. 15-52 at 44.
} 
need for mutual accommodation to the extent possible through marine spatial planning and related regulatory tools. ${ }^{4}$

Conflicts between OWFs and shipping raise further legal concern because navigation through zones of national jurisdiction and on the high seas can be characterized as a "sacrosanct" international right. International navigation has received extensive protection in the United Nations Convention on the Law of the Sea, 1982 (LOS Convention), ${ }^{5}$ which is widely considered as the "constitution" for the world's oceans. The LOS Convention obliges coastal States to respect, take into consideration and accommodate international navigation in national maritime zones while exercising their rights. Coastal State OWF plans that potentially impede international navigation necessitate requests for appropriate routeing measures to the International Maritime Organization (IMO), the leading competent international organization concerned with international navigation and shipping and whose multiple roles in this regard are established in the LOS Convention. ${ }^{6}$

This article addresses two key questions against the above backdrop. First, how does the law of the sea balance the interests of coastal States in establishing and operating OWFs in national maritime zones with the interests of other ocean users, most especially navigational uses? This question is important as it speaks to the coastal State's authority in national maritime zones and beyond and the rights of the international community in those spaces. While the LOS Convention provides a framework for the emplacement and operation of OWFs in national maritime zones, the full extent of regulatory authority with regard to OWFs is not always clear. Second, to what extent and in what manner might maritime safety regulatory approaches and tools be employed as integral components of marine spatial plans to address the needs of OWFs and help avoid and/or manage potential conflicts at an operational level? This question draws on international maritime regulation, understood for the purposes of this article to broadly include applicable conventions, codes, guidelines and generally accepted international rules, standards and practices. The second question is important from conflict avoidance and management perspectives because it identifies available regulatory and recommended tools, including area-based management measures, to accommodate potentially conflicting uses and promote maritime safety and environment protection. Such tools help operationalize marine spatial planning and potentially point to best practices for conflict avoidance and management.

\footnotetext{
${ }^{4}$ On the imperatives of MSP in multi-ocean use environments, see F. Douvere \& C. Ehler, "Ecosystem-Based Marine Spatial Management: An Evolving Paradigm for the Management of Coastal and Marine Places," Ocean Yearbook, vol. 23 (2009): 1-26.

${ }^{5}$ United Nations Convention on the Law of the Sea, Montego Bay, 10 December 1982, 1833 UNTS 3 [hereafter cited as "LOS Convention"].

${ }^{6}$ United Nations, Division for Ocean Affairs and the Law of the Sea, Competence of Relevant International Organizations under the United Nations Convention on the Law of the Sea, Law of the Sea Bulletin No. 31, Part III at 79-95, available online: <http://www.un.org/depts/los/doalos_publications/LOSBulletins/bulletinpdf/bulletinE31.pdf>. Other international organizations that enjoy a measure f competence with regards to shipping include the United Nations Conference on Trade and Development (UNCTAD), United Nations Commission on International Trade Law (UNCITRAL) and the International Labour Organization (ILO). See A. Chircop, "The International Maritime Organization," in The Oxford Handbook on the Law of the Sea, eds. Donald R. Rothwell, A.G. Oude Elferink, K.N. Scott \& T. Stephens (Oxford: Oxford University Press, 2015), 416-438 at 416. As will be discussed below, the International Hydrographic Organization (IHO) also has an important role to play with regard to the setting of standards for international navigation charts.
} 
The article starts by setting out the technological context of OWFs, in particular the nature and potential extent of their spatial footprint inclusive of the infrastructure that brings wind energy to markets, and the potential interactions and functional impacts on other ocean users. The next phase of the discussion considers pertinent jurisdictional frameworks and rules in the international law of the sea with particular emphasis on coastal State rights and jurisdictions as they apply to OWFs and the rules that protect international navigation rights as counterweight. This is followed by a discussion of the role of key international organizations and the tools and procedures available for accommodating international navigation rights with coastal State initiatives that have the potential to affect navigation. The article concludes with two principal observations, first, regarding the emerging pragmatic and functional practices of accommodating the safety needs of windfarms with the imperatives of international rights and, second, insights into the dynamic relationship between the international law of the sea and international maritime law.

\section{THE OWF "FOOTPRINT"}

\subsection{General considerations}

OWFs tend to occupy large ocean spaces on an exclusive basis for the long term. They consist of space intensive arrays and accompanying safety zones of possibly varying breadths. They are accompanied by subsea structures and cables. ${ }^{7}$ They potentially produce a range of impacts, including on local wind \& visibility conditions, possible displacement of international shipping and inshore navigation routes, low overflight, possible displacement of fishing recreational uses, increased danger of allisions with array, enhanced danger of collisions in narrower channels, and interference with radar functionality.

Fortunately, there are international rules, standards and practices arising from other ocean uses that may provide guidance in accommodating OWFs and guiding their interactions with other ocean uses. Of particular interest here are the offshore oil and gas, submarine cable and shipping industries. The development of the law of the sea and international maritime law was influenced significantly by these uses and consequently, and as will be seen below, several provisions in the law of the sea and maritime conventions address the concerns of those ocean industrial uses. The international rules have been drafted at a high level of generality, providing for their extension to new ocean uses. For example, analogously to the offshore oil and gas industry, OWFs are space intensive users through the use of installations and structures. OWFs employ arrays consisting of clusters of wind turbines, protected by safety zones, and interconnected by submarine power and fibre optic cables. The cables are organized in grid networks similarly to pipeline networks. Like the oil and gas industry, the offshore wind energy industry has developed a range of new vessels that require new dedicated rules for classification. Servicing vessels and cables may well cross international maritime boundaries, as could communication cables and pipelines. Both OWFs and

\footnotetext{
${ }^{7}$ For studies on the legal, policy, management and technical aspects of submarine cables, see D.R. Burnett, R.C. Beckman \& T.M. Davenport, eds., Submarine Cables: The Handbook of Law and Policy (Leiden: Martinus Nijhoff, 2014). For the history of cables and the industry behind them, see: S. Ash, "The Development of Submarine Cables," id, pp. 19-39; M. Green, “The Submarine Cable Industry: How Does it Work?” Id, pp. 41-60.
} 
offshore oil and gas installations employ a varied labour force that includes unique categories of maritime workers. That labour force may or may not include seafarers, raising questions regarding the occupational health and safety regulation of non-seafarers, a topic for another article.

There are also important differences from uses that rely on offshore installations and structures. Unlike oil and gas installations, the structures forming the array in the OWF have reduced capability to accommodate personnel and servicing equipment. Wind turbines and their ancillary structures may or may not have a landing pad. Servicing these turbines will be accomplished exclusively with specialized installation, maintenance and crew accommodations vessels or helicopters. Consequently, there can be frequent vessel support and movement, although supply vessels for oil installations also create traffic. There tends to be wider dispersal of workers, with fewer at any one site. This has implications for responding to emergencies. Different from shipping, offshore supply and servicing vessels are not easily captured by port state control regimes. ${ }^{8}$ A full appreciation of the particular spatial and functional characteristics of OWFs requires appreciation of the technologies and practices involved, which are discussed next.

\subsection{Spatial impacts}

\subsubsection{Wind turbines}

Wind turbines convert the wind's kinetic energy into electricity. ${ }^{9}$ Offshore wind turbines are structurally similar to their land-based counterparts and are comprised of three main components: the tower, the nacelle and the rotor assembly. ${ }^{10}$ The tower typically takes the form of a hollow steel cylinder mounted on an offshore substructure. Typically, a landing platform is fitted at the tower's base permitting personnel to access the turbine from support vessels. Internally, the tower will house either a lift or a ladder permitting service personnel to access the nacelle. It may also house electrical equipment, in addition to limited accommodations in the event that extreme conditions force personnel to remain within the tower. The tower height, reported as hub height, is dictated by three principle factors: the rotor diameter; the minimum height above sea level required for the lowermost extremity of the rotor dictated by national regulations; and site specific considerations. ${ }^{11}$ In 2013 , the average hub height of offshore wind turbines was $89 \mathrm{~m} .{ }^{12}$

\footnotetext{
${ }^{8}$ This is due to the fact that the voyage to the OWF may not be international and the port time may be limited, making them relatively invisible to port state control. See Results of Focal Point Correspondence for Identification of the IMO technical Standards that are Applicable to Ships Involved in Offshore Industries, Submitted by the United Kingdom, IMO Doc. DE/12, 14 December 2015, p. 5.

${ }^{9}$ Committee on Offshore Wind Energy Turbine Structural and Operating Safety, Structural Integrity of Offshore Wind Turbines: Oversight of Design, Fabrication and Installation, Transportation Research Board, Report no. 305 (Washington, D.C.: Transportation Research Board of the National Academies, 2011), p. 2 [hereafter cited as "Structural Integrity of Offshore Wind Turbines"].

${ }^{10}$ C. K. Tvieten, E. Albrechtsen, J. Heggset, M. Hofmann, E. Jersin, B. Leira, P. K. Nordall, "HSE challenges related to offshore renewable energy: a study of HSE issues related to current and future offshore wind power concepts," SINTEF Technology and Society Safety Research (2011), p. 21.

${ }^{11}$ For example, Denmark requires $20 \mathrm{~m}$ between the highest astronomical tide and the lowermost extremity of the turbine blades while the UK requires $22 \mathrm{~m}$. These measures are in place to protect small craft navigating in the vicinity of the turbine.

${ }^{12}$ Fraunhofer Institute for Wind Energy and System Technology, Wind Energy Report Germany 2013 (Kassel, Germany: Fraunhofer IWES, 2013), p. 54 [hereafter cited as “Wind Energy Report Germany 2013”]
} 
The nacelle connects to the top of the tower by means of a yaw gearing, which permits the nacelle to rotate 360 degrees enabling the rotor assembly (described below) to face the direction of the wind. It houses the mechanical equipment required to manipulate the pitch and the speed of the turbine blades, in addition to the electrical generators employed to produce electricity. The nacelles of current generation offshore wind turbines are sufficiently large to afford personnel internal access to electrical and mechanical systems. Those of the largest class of offshore wind turbines come equipped with helicopter landing platforms to permit personnel aerial access. Offshore wind turbines typically possess a rotor assembly composed of three compositemanufactured blades projecting vertically outwards from a central hub. The pressure exerted by the wind on the turbine blades causes them to rotate, turning a driveshaft that engages the electrical generators housed in the nacelle enabling them to produce power.

Despite similarities between land-based and offshore wind turbines, the offshore environment presents engineering challenges that are absent on land, requiring modifications to the turbine's structural configuration. First, towers must be built to withstand the unique combination of loading forces caused not only by exposure to wind, but also to waves and currents. Second, all components must be marinized to withstand the corrosion caused by a hostile saline environment. ${ }^{13}$ To achieve this, nacelles are pressurized so as to remain air- and watertight. Additionally, all exterior surfaces are finished in high-grade marine coatings. Third, offshore wind turbines are typically equipped with condition monitoring systems which diagnose and resolve problems remotely, reducing overall reliance on offshore service personnel. Fourth, towers must be fitted with marine and aerial navigation lights and markings. Accompanying these challenges are the unique advantages that developing turbines offshore present, primarily related to stronger and steadier wind resources, closer proximity to coastal load centres, and the lack of height and noise restrictions. Turbine manufacturers have exploited these comparative advantages by enlarging turbine dimensions; exploiting the positive relationship between rotor diameter and generating capacity to develop increasingly powerful wind turbines. Currently, commercial manufacturers are producing turbines for the offshore sector with $6 \mathrm{MW}$ generating capacities and developing turbines with 10, 15 and 20MW generating capacities. ${ }^{14}$

OWFs are composed of a series of individual wind turbines installed in arrangements called arrays. The spacing within and between rows of individual turbines is determined with a view to minimizing turbulence between individual turbine units in order to maximize power output. It typically equals a distance that is seven times greater than the turbine rotor diameter - an average $800 \mathrm{~m}$ in $2013 .{ }^{15}$ However, wind turbine arrays may be more densely spaced at distances $2-3$ times greater than the rotor diameter - between 230 and 350m in $2013 .{ }^{16}$ Wind turbine arrays may be regularly spaced in a linear series or a grid pattern, or, irregularly spaced to account for site-specific factors such as the location of shipping lanes. Modern OWFs display arrays composed of an

\footnotetext{
${ }^{13}$ As of 2014, the vast majority of operational wind farms are based in ocean settings, rather than fresh water.

${ }^{14}$ Jos Beurskens, Achieving the 20 MW Wind Turbine, Renewable Energy World, available online: < http://www.renewableenergyworld.com/rea/news/article/2011/06/achieving-the-20-mw-wind-turbine>.

${ }^{15}$ Wind Energy Report Germany 2013, see n. 12 above, 54.

${ }^{16}$ Id.
} 
increasing number of individual turbines. ${ }^{17}$ This trend, when combined with the increasing scale of offshore wind turbines and corresponding requirement for greater distances between them, anticipates an expanding footprint of OWFs.

\subsubsection{Turbine substructure and foundations}

Two primary methods exist for mounting offshore wind turbines: fixed or floating substructures or foundations. The choice of substructure or foundation is dictated by the wind turbine's size and site-specific considerations, including water depth, bottom conditions and broader environmental considerations, such as wind, wave, current and ice conditions. Currently, the vast majority of offshore wind turbines mount to fixed substructures or foundations in an average water depth of $13 \mathrm{~m} .{ }^{18}$ However, the maturation of offshore substructure technology is permitting the deployment of fixed and floating substructures in waters of increasing depth, dramatically increasing the potential to harness wind resources offshore. There are six principle types of fixed substructures or foundations: monopile; gravity base; jacket; tripod; tri-pile; and suction bucket. A small number of wind turbines are mounted to floating substructures, of which there are two principle types, namely spar buoy and semi-submersible. The ensuing discussion will consider the three most common types of fixed substructures and the two types of floating substructures, the extent of their application and their respective qualities.

The monopile is the most common of the five types of fixed substructures, accounting for $76 \%$ of all offshore substructures installed in Europe in $2013 .{ }^{19}$ A monopile is a steel cylinder with a diameter of up to $6 \mathrm{~m}$, a wall thickness of up to $80 \mathrm{~mm}$ and a length dictated by the water and embedment depth. ${ }^{20}$ Transition pieces connect to the portion of the monopile protruding above the ocean's surface, forming a level platform on which to mount the turbine. Specialized construction vessels pile drive the monopiles into the sea floor in water depths of up to 40m but more commonly in average water depths of $13 \mathrm{~m}$. Monopiles cannot be installed in locations characterized by stony bottom conditions. The gravity base is the second most common type of fixed substructure, accounting for $12 \%$ of all offshore substructures installed in Europe in 2013. ${ }^{21}$ Gravity bases are large concrete foundations designed to rest on the sea floor and project above the ocean's surface. Gravity bases require extensive bottom preparation, but do not require piling. They are commonly deployed in water depths of $10 \mathrm{~m}$ but may be installed in depths of up to $40 \mathrm{~m}$. Jacket foundations are the third most common type of fixed substructure, accounting for $5 \%$ of all offshore substructures installed in Europe in 2013. ${ }^{22}$ Jacket foundations consist of steel lattice forming a

\footnotetext{
${ }^{17} \mathrm{Id}$.

${ }^{18}$ European Wind Energy Association, “The European Offshore Wind Industry: Key Trends and Statistics," a report by the European Wind Energy Association (January 2013), p. 13, available online: < http://www.ewea.org/fileadmin/files/library/publications/statistics/EWEA-European-Offshore-Statistics-2014.pdf> [hereafter cited as "EWEA Key Trends and Statistics 2014”].

${ }^{19} \mathrm{Id}$.

${ }^{20}$ M. Beyer and W. Brunner, "New Bauer Flydrill System: Drilling monopiles at Barrow offshore wind farm UK," (Schrobenhausen, Germany: BAUER Maschinen GmbH, 2005), p. 3, available online: <http://wind.nrel.gov/public/SeaCon/Proceedings/Copenhagen.Offshore.Wind.2005/documents/papers/Installation_ Concepts_and_risks/W.Brunner_New_BAUER_Flydrill_systemdrillingmonopiles.pdf $>$.

${ }^{21}$ EWEA Key Trends and Statistics 2014, see n. 18 above, p. 13.

${ }^{22} \mathrm{Id}$.
} 
tower, the foot of which attaches to the sea floor by means of four piles. They may be installed in water depths of up to $60 \mathrm{~m}$ but cannot be installed in locations characterized by stony bottom conditions due to the requirement for piling. Floating substructures are currently in their developmental stage. However, they offer considerable promise by permitting access to wind resources in water depths exceeding $100 \mathrm{~m}$ dramatically expanding access to harvestable wind resources. Additionally, floating substructures have the potential to facilitate the mass production and deployment of offshore wind turbines, reducing reliance on costly offshore installation operations. There are a number of concepts in existence that can be summarized into spar buoys and semi-submersibles. Spar buoys are cylindrical steel tubes approximately $100 \mathrm{~m}$ in length, which project below the ocean's surface and are ballasted to remain upright. They are anchored to the sea floor at multiple points and the turbine is mounted on top of the buoy. Currently, spar buoys are designed for deployment in water depths of between 300 and $700 \mathrm{~m} .^{23}$ Semi-submersibles consist of a series of ballasted pontoons which float below the water's surface, supporting a platform that projects above the water's surface and which mounts the turbine. They are anchored to the sea floor at multiple points and have been successfully deployed as prototypes in Europe, North America and Asia.

\subsubsection{Submarine cables}

OWFs employ submarine power cables to deliver the power generated by individual turbines to land-based consumers. Individual turbines generate power at ranges between 480 and 690V, which is increased to a distribution voltage of approximately $33 \mathrm{kV}$ by individual turbine transformers. ${ }^{24}$ For smaller OWFs or those closer to shore, power may be brought directly to shore via submarine electrical cables and injected into the grid at distribution voltage. ${ }^{25}$ However, for larger OWFs or those at greater distances from shore, which represent the growing share of installed capacity, inter-array submarine electrical cables channel the power generated by individual turbines to one or multiple offshore substations. The substations then increases that power to a transmission voltage of approximately $133 \mathrm{kV}$ to be exported via a submarine electrical cable and connected to the onshore grid. ${ }^{26}$ Fibre optic lines typically accompany the electrical export cable to facilitate remote systems monitoring of the OWF. ${ }^{27}$ Currently, improvements in submarine electrical cable technology are permitting OWF development at increasing distances from shore by minimizing losses associated with transmission. Such improvements, coupled with the development of deepwater deployment technologies, are dramatically expanding the potential to harness offshore wind energy resources at greater distances from shore and in waters of increasing depth.

23 In 2009, Norway's Statoil deployed the world's first spar buoy concept floating turbine. Available online: <http://www.statoil.com/en/TechnologyInnovation/NewEnergy/RenewablePowerProduction/Offshore/Hywind/Page s/HywindPuttingWindPowerToTheTest.aspx?redirectShortUrl=http $\% 3 a \% 2 \mathrm{f} \% 2 \mathrm{fwww}$. statoil.com\%2fhywind $>$.

${ }^{24}$ Structural Integrity of Offshore Wind Turbines, see n. 9 above, p. 25.

${ }^{25} \mathrm{Id}$.

${ }^{26}$ P. A. Lynn, Onshore and Offshore Wind Energy: An Introduction (Chichester: John Wiley \& Sons Ltd, 2012), pp. 175-77.

${ }^{27}$ Id., p. 168. 


\subsubsection{Offshore substations}

Offshore substations house the transformers and electrical equipment required to aggregate the power generated by individual offshore turbines and increase its voltage to approximately $133 \mathrm{kV}$ prior to its transmission to the onshore grid. They are typically mounted on steel jacket structures or monopiles within the boundaries of the wind farm. As the generating capacity of an OWF increases, the scale or number of offshore substations required will increase correspondingly. Offshore substations may also act as central service and accommodation platforms for an OWF and its personnel, housing amenities such as data monitoring and control systems, maintenance facilities, and personnel accommodations. ${ }^{28}$

\subsubsection{OWF construction vessels and support craft}

Globally, there is an expanding fleet of specialized OWF construction vessels and support craft. A detailed survey of the 18 types of vessels required during an OFW's lifecycle is outside this article's scope. ${ }^{29}$ However, the diverse vessels involved in OWF operations are identified in order to illustrate an OWF's broader spatial footprint and the scope of its interactions with other marine users. Specialized construction vessels include pile-driving vessels, heavy lift vessels, jack-up barges, cargo barges and other vessels with the capacity to transport, lift and install OWF components comprising the substructure, turbine tower, rotor assembly and offshore substation. ${ }^{30}$ Vessels involved in other offshore sectors which also engage in OWF construction include dredgers, surveying vessels (remotely-operated vehicle support, geophysical survey, geotechnical survey, and multi-purpose survey), cable installation vessels, diving support vessels and various service operations vessels. ${ }^{31}$ Support vessels and craft include specialized personnel transfer vessels designed to safely transfer and disembark service technicians on platforms at the turbine's base in a variety of sea conditions, service operations vessels designed to perform light and heavy maintenance during a wind farm's lifecycle, crew accommodations vessels, and emergency response vessels. ${ }^{32}$ Currently, there is a strong upward trend in the scale of newly commissioned OWF construction vessels designed to accommodate the increasing size of offshore wind turbines, transport an increasing number of turbines to the installation site, and operate in deeper waters. ${ }^{33}$ Accordingly, the increasing diversity, quantity and scale of vessels involved in the offshore wind

\footnotetext{
${ }^{28}$ Structural Integrity of Offshore Wind Turbines, see n. 9 above, p. 26.

${ }^{29}$ Navigant Consulting, Inc., Global Evaluation of Offshore Wind Shipping Opportunity presented to The Danish Ship Owners' Association, London, U.K., 19 December 2013, p. 10 [hereafter cited as "Evaluation of Offshore Wind Shipping Opportunity"].

${ }^{30}$ A jack up barge possesses four vertical legs that lower to the sea floor and are used to mechanically raise, or "jackup" the barge in order to form a stable working platform unaffected by waves. A jack up barge's legs may be raised while the vessel is in transit; C. K. Tvieten, E. Albrechtsen, J. Heggset et al., "HSE challenges related to offshore renewable energy: a study of HSE issues related to current and future offshore wind power concepts," SINTEF Technology and Society Safety Research (2011), pp. 26-52.

${ }^{31}$ Evaluation of Offshore Wind Shipping Opportunity, see n. 29 above, p. 10.

${ }^{32}$ Id.

${ }^{33}$ Roland Berger Strategy Consultants, Offshore Wind Toward 2020: On The Pathway to Cost Competitiveness, April 2013 16 available online: http://www.rolandberger.com/media/pdf/Roland_Berger_Offshore_Wind_Study_20130506.pdf>.
} 
energy sector correspond to an expanding spatial footprint of OWFs in the marine environment a trend accompanied by an increased potential for conflicts with other marine users.

\subsection{Functional impacts}

\subsubsection{Navigational issues}

A large OWF may occupy a marine area exceeding $100 \mathrm{~km}^{2}$ for the duration of its lifecycle, ${ }^{34}$ which could be a minimum of 20-25 years. Such a large areal allocation, when coupled with the increasing global deployment of OWFs, depicts an extensive and growing marine spatial use. Further, because OWFs may be preferentially deployed in proximity to coastal load centres that may also be international shipping hubs, they have the potential to present significant challenges with respect to navigation.

One of the primary navigational hazards associated with OWFs is the increased risk of ship-to-ship collisions due to greater congestion in marine areas outside the wind farm's boundaries. ${ }^{35}$ An OWF may encroach on an existing sea lane, forcing maritime traffic into an increasingly confined area and raising the likelihood of collision between ships. A second hazard relates to the risk of allision between ships, either powered or drifting, and offshore wind turbines and their associated infrastructure. ${ }^{36}$ Allision and collision hazards encompass those encountered by recreational yachts, fishing, military and other vessels. An interesting legal issue is to what extent a physical contact between a traditional vessel and a floating wind turbine will be considered as a collision or an allision. ${ }^{37} \mathrm{~A}$ third hazard relates to the reduced ability for ships restricted in their ability to manoeuvre to navigate in the vicinity of OWFs. ${ }^{38}$ This risk will apply to special

\footnotetext{
${ }^{34}$ Representing the total area of the London Array which is the OWF with the greatest generating capacity currently in operation globally. Available online: < http://www.londonarray.com/the-project/>.

${ }^{35}$ For the purposes of this paper, hazard will be defined according to the Canadian Centre for Occupational Health and Safety: A hazard "is any source of potential damage, harm or adverse health effects on something or someone under certain conditions at work"; available online: http://www.ccohs.ca/oshanswers/hsprograms/hazard_risk.html>; RenewableUK, "Offshore Wind and Marine Energy Health and Safety Guidelines,” prepared by SgurrEnergy Ltd. for RenewableUK (2014: Issue 2), pp. $212-216$.

${ }^{36}$ Energinet.dk, Horns Rev 3 Offshore Wind Farm: Navigational Risk Analysis, February 2014, pp. $23-41$.

${ }^{37}$ In part this depends on whether the floating wind turbine can be characterized as a "ship", thus subjecting it to the institutions of maritime law, including maritime safety regulation, ship registration, registrable securities (such as mortgage), and susceptibility to arrest and action in rem proceedings. Floating turbines may be analogized to floating offshore platforms and potentially may be moved from one location to another. However, the law regarding their possible legal status in maritime law is uncertain at this time. See A. Severance \& M. Sandgren, "Flagging the Floating Turbine Unit: Navigation Towards a Registerable, First-Ranking Security Interests in Floating Wind Turbines," Tulane Maritime Law Journal, 39 (2014): 1-83.

${ }^{38}$,Convention on the International Regulations for Preventing Collisions at Sea, London, 20 October 1972,1050 UNTS 16, Rule 3(g) [hereafter cited as "COLREGS"] defines a vessel restricted in her ability to manoeuvre as: "a vessel which from the nature of her work is restricted in her ability to manoeuvre as required by these Rules and is therefore unable to keep out of the way of another vessel. The term "vessels restricted in their ability to manoeuvre" shall include but not be limited to:

(i) a vessel engaged in laying, servicing or picking up a navigation mark, submarine cable or pipeline;

(ii) a vessel engaged in dredging, surveying or underwater operations;

(iii) a vessel engaged in replenishment or transferring persons, provisions or cargo while underway;

(iv) a vessel engaged in the launching or recovery of aircraft;
} 
purpose vessels not under their own power, vessels encountering mechanical difficulties and all vessels facing adverse weather or sea state conditions. These hazards threaten the property of turbine operators and ship owners. Additionally, they are a maritime safety concern because of the exposure of OWF construction and operations personnel, as well as seafarers, to risks associated with a vessel-turbine allision.

The severity and risk of these hazards will increase according to an OWF's proximity to shipping lanes, the density and scale of marine traffic in contiguous areas, as well as factors relating to the prevailing winds, currents and wave patterns. ${ }^{39}$ It is important to note that an average installation depth of $13 \mathrm{~m}$ may mitigate the allision threats posed by deep draught vessels. ${ }^{40}$ However, this mitigation effect is likely to decrease as OWFs move further offshore.

\subsubsection{OWF Submarine electrical cables and navigation}

An OWF's marine spatial profile encompasses the submarine electrical cables that (a) interconnect individual turbines and (b) export power from the offshore array to the land-based grid. ${ }^{41}$ These cables may impinge on the ability of surface vessels to anchor in the vicinity of an OWF or the corridor through which its export cable runs, potentially characterized as an exclusion zone. This may lead to congestion in a contiguous area. Additionally, it creates a navigational hazard by compromising the ability of all vessels to anchor in certain areas in case of need and by doing so, denying recourse to a critical safety procedure. At international law, a vessel that sacrifices an anchor in order to avoid damaging a submarine cable is entitled to compensation. ${ }^{42}$ Additionally, the submarine power cables accompanying OWF operations may pose risks to or displace other marine uses such as fishing operations involving trawling and dredging operations, among others. $^{43}$

Although this risk may be mitigated through either cable burial or protection, the erosion or scouring of sediment on the sea floor by either currents or weather may expose a previously buried cable and increase the risk for conflicts with other marine users. ${ }^{44}$ Further, the anchors of

(v) a vessel engaged in mine clearance operations;

(vi) a vessel engaged in a towing operation such as severely restricts the towing vessel and her tow in their ability to deviate from their course."

${ }^{39}$ For the purposes of this paper, risk will be defined according to the Canadian Centre for Occupational Health and Safety: A risk "is the chance or probability that a person will be harmed or experience an adverse health effect if exposed to a hazard"; available online: 〈http://www.ccohs.ca/oshanswers/hsprograms/hazard_risk.html〉.

${ }^{40}$ EWEA Key Trends and Statistics 2014, see n. 18 above, p. 13.

${ }^{41}$ On power cables see M. Eccles, J. Ferencz \& D. Burnett, "Submarine Power Cables," in Burnett et al., see n. 7 above, pp. 225-236.

42 Convention for the Protection of Submarine Telegraph Cables, Paris, 14 March 1884, art VII. See also the International Cable Protection Committee, About Submarine Electrical Cables, available online: < http://www.iscpc.org/publications/About_SubPower_Cables_2011.pdf >. For a commentary on the international law governing submarine cables, see D. Burnett, T. Davenport \& R. Beckman, "Overview of the International Legal Regime Governing Submarine Cables," in in Burnett et al., see n. 7 above, pp. 63-90.

${ }^{43}$ M. Sharples, "Offshore Electrical Cable Burial For Wind Farms: State of the Art, Standards and Guidance \& Acceptable Burial Depths, Separation Distances and Sand Wave Effects," prepared for the Bureau of Ocean Energy Management, Regulation \& Enforcement - Department of the Interior, (November 2011), p. 111.

${ }^{44}$ Id., p. 122. 
large ships may scour and penetrate the sea floor and foul an electrical cable even at a burial depth of one metre, the current industry standard. ${ }^{45}$ Moreover, the development of floating wind turbines displaying umbilical electrical cables which span the water column creates an increased potential for conflicts with other marine users.

\subsubsection{Electro-Magnetic interference with radar}

OWFs potentially interfere with radar systems and compromise the ability of shipping, aviation, and other users to interpret data for the purpose of navigation, air-traffic control, weather forecasting and other applications. ${ }^{46}$ Wind turbine arrays and the turbulent air generated by the blade rotation carries a signature appearing on traditional radar systems as a form of clutter. ${ }^{47}$ This clutter interferes with the radar generated image, providing an incomplete picture of the activity in the OWF's environs. ${ }^{48}$ The implications of this interference are manifold. For example, it may prevent air traffic control authorities from detecting the existence of a plane in the air column above or in the shadow of an OWF. Alternatively, it may produce a false aircraft track. ${ }^{49}$ For marine radar users, it may reduce the ability of shipping to detect the presence of vessels in the affected area. For weather radar, it may generate false readings of meteorological disturbances, negatively impacting forecasting accuracy. ${ }^{50}$

Among these impacts, some are worse than others. OWF interference with radar systems has been greater for air traffic and weather users than it has been for marine users. ${ }^{51}$ However, OWF radar interference continues to impact safety of navigation for aerial, marine and other users, including fisheries and the military.

\subsubsection{Interactions with other users}

The presence of an OWF changes the seascape in a manner that will impact other marine users. There is an increased potential for conflicts between marine users seeking to exercise their respective functions within a finite area of marine space. As a corollary, competing marine users, such as the offshore cable and petroleum sectors among others, face changed operating environments that will demand revisions to operating procedures, navigational practices and maritime safety generally to accommodate OWFs.

Within the offshore cable sector, the presence of an OWF may require re-routeing a submarine cable due to physical obstruction and the impossibility of operating cable surveying and

45 International Cable Protection Committee, About Submarine Electrical Cables, available online: < http://www.iscpc.org/publications/About_SubPower_Cables_2011.pdf>.

${ }^{46}$ M. Brenner, S. Cazares, M. J. Cornwall, et al., Wind Farms and Radar (McLean, Virginia: The MITRE Corporation, 2008), p. 5.

${ }^{47}$ Id., p. 5.

48 Id., p. 5.

${ }^{49}$ Civil Aviation Authority, “CAA Policy and Guidelines on Wind Turbines,” CAP 764 (May 3013), p. 26.

${ }^{50}$ D. Varga, J. Matthews, L. Norins et al., "Mitigation Techniques to Reduce the Impact of Wind Turbines on Radar Services," Energies 6 (2013): 2859-2875 at 2862.

${ }^{51}$ Id. 
installation vessels within the area or in proximity to the wind farm. ${ }^{52}$ The submarine electrical cables employed by OWFs may place an obligation on cable developers to undertake increasingly complex cable crossing logistics. ${ }^{53}$ The erosion of sediment on the sea floor by currents interacting with the subsea components of an OWF may either expose previously protected or bury existing cables, demanding the mobilization of operations and maintenance vessels. ${ }^{54}$ In a similar fashion, the existence of an OWF may obstruct or alter offshore petroleum installation placement, support vessel navigation and submarine pipeline routing. This dynamic interaction between the offshore renewable energy sector, cable, petroleum and other sectors confronts marine users with a new and evolving set of hazards which coastal States need to address. This article next considers the coastal State jurisdictional framework in the law of the sea and how it affects the designation, establishment and operation of OWFs.

With respect to aircraft, OWFs and their associated infrastructure pose a physical obstacle to low flying aircraft, including military, as well as search and rescue, by virtue of heights above the ocean surface which may exceed $200 \mathrm{~m} .{ }^{55}$ This exposes aviators, mariners and persons or entities which are the target of low flying aircraft to a significant hazard in the form of complete or partial obstruction to overflight below certain altitudes in the air column above OWFs.

\section{BALANCING MARITIME JURISDICTION AND NAVIGATION RIGHTS}

\subsection{Overall approach}

The international law of the sea strikes a delicate balance between coastal State rights in national maritime zones and other international ocean use rights, in particular navigation. Throughout the Third United Nations Conference on the Law of the Sea, 1973-1982 and in the ensuing LOS Convention, international navigation rights were a core concern and their protection was an essential part of the package that eventually provided coastal States with enhanced jurisdiction over ocean space. ${ }^{56}$ The international navigation rights consist of innocent passage through internal waters which were formerly high seas, archipelagic sea lanes, passage in archipelagic waters, innocent passage through the territorial sea, transit passage through straits used for international navigation, and freedom of navigation over the continental shelf and on the high seas. Cumulatively, these rights ensure that international navigation is protected in the vast majority of ocean spaces. The utilization of ocean space by coastal States for OWF purposes must be cognizant of these international rights. When international navigation rights in national maritime zones are provided specific protection the LOS Convention, the effect is not necessarily to deny the coastal

\footnotetext{
52 W. Nielsen and T. Davenport, "Submarine Cables and Offshore Energy," in Submarine Cables: The Handbook of Law and Policy, eds. D. Burnett, R. Beckman and T. Davenport (Leiden: Martinus Nijhoff, 2014), p. 371.

${ }^{53}$ Id.

${ }^{54}$ Id.

${ }^{55}$ Structural Integrity of Offshore Wind Turbines, see n. 9 above, p. 18.

56 States regularly monitor practices that encroach on international navigation rights. In particular, since 1983 the United States has maintained the Freedom of Navigation Program by virtue of which it exercises and asserts "its navigation and overflight rights and freedoms on a worldwide basis in a manner that is consistent with the balance of interests reflected in the Law of the Sea (LOS) Convention": US Department of State, available online: <http://www.state.gov/e/oes/ocns/opa/maritimesecurity/>.
} 
State use of ocean space within national jurisdiction, but rather to introduce a process of mutual accommodation of the respective rights based on consultative procedures through the IMO.

The expected process of mutual accommodation varies depending on the ocean space concerned. In general, it is useful to distinguish between maritime zones over which the coastal State enjoys sovereignty (e.g., internal waters, archipelagic waters and territorial sea), ${ }^{57}$ other maritime zones where the coastal State enjoys particular sovereign rights and jurisdictions, but falling short of sovereignty (e.g., contiguous zone, exclusive economic zone, continental shelf) ${ }^{58}$ and high seas areas. ${ }^{59}$ Within its maritime zones, the coastal State may exercise sovereignty, sovereign rights or jurisdiction, as the case may be, in designating, establishing and operating OWFs. In doing so, coastal States must exercise their rights in a manner that is sensitive to and consistent with international navigation rights. The balance between coastal State rights and international navigation rights is carefully calibrated in each maritime zone (described in the Annex to this article and discussed in detail below).

\subsection{OWFs in ocean areas subject to sovereignty}

Sovereignty may be described as the totality of powers and jurisdictions that the coastal State enjoys over designated ocean spaces. Internal waters consist of marine areas enclosed landward of the straight baselines delineated along a highly indented coastline or fringes of islands for the purpose of measuring the breadth of the 12-nautical mile (M) territorial sea and other maritime zones. ${ }^{60}$ While sovereignty connotes exclusive powers, a delicate balance is achieved in these spaces through, on the one hand, acknowledging coastal State sovereignty attributes in the ocean space concerned, such as the authority to legislate, and, on the other hand, providing constraints on the exercise of its rights with respect to international navigation.

\subsubsection{Internal waters}

With one exception, ${ }^{61}$ there is no right of international navigation right through internal waters. Internal waters are waters landward of the baselines of the territorial sea (which include the low water line and straight lines delineated along highly indented coastlines and along the outermost points on the seaward side of islands fringing the coast), ${ }^{62}$ and waters enclosed by a straight line closing a river mouth ${ }^{63}$ and bays of particular dimensions. ${ }^{64}$ The consequence is that in internal waters the coastal State may re-route navigation to carve out space for exclusive use by an OWF (and all ancillary installations and structures) and its safety zone without any restriction.

\footnotetext{
${ }^{57}$ LOS Convention, see n. 5 above, arts 2 and 49.

${ }^{58}$ Id., respectively arts $33,55-56$ and 76-77.

${ }^{59}$ The term "freedom of navigation" is given meaning by the provisions of Part VII of the LOS Convention, see n. 5 above.

${ }^{60}$ Id., arts 7-8.

61 Id., art 8 .

${ }^{62}$ Id., art 7.

${ }^{63}$ Id., art 9.

${ }^{64} \mathrm{Id}$., art 10. The bay, which is a well-marked indentation rather than a mere curvature of the coast, must belong to a single State and must satisfy the semi-circle rule, including a 25M limit on the closing line between the natural entrance points of the bay.
} 


\subsubsection{Archipelagic waters}

Similarly, archipelagic waters are marine areas enclosed within archipelagic baselines delineated by qualifying States for the purpose of determining the breadth of the territorial sea and other maritime zones. ${ }^{65}$ An archipelagic State wishing to establish an OWF that affects international navigation must consider the limits of its rights and international procedures. The archipelagic State enjoys sovereignty over archipelagic waters, but that sovereignty has to be exercised subject to the LOS Convention provisions for such States. ${ }^{66}$ The right of innocent passage normally applicable in the territorial sea applies to archipelagic waters subject to the provisions on the right of archipelagic sea lanes passage. ${ }^{67}$ This means that the archipelagic State may regulate passage with regard to a range of matters of particular relevance to OWFs, including maritime safety (e.g., traffic around the OWFs and safety zones, vessels servicing OWF installations), protection of facilities and installations (e.g., wind turbines) and protection of cables (e.g., for produced power and communications). ${ }^{68}$

The archipelagic State may designate sea lanes and air routes suitable for the exercise of continuous, expeditious and unobstructed transit, including establishment of traffic separation routes in accordance with particular rules. ${ }^{69}$ They must conform to generally accepted international regulations, ${ }^{70}$ the most significant of which are set out under the International Convention for the Safety of Life at Sea, 1974, as amended. ${ }^{71}$ Most important, "in designating or substituting sea lanes or prescribing or substituting traffic separation schemes" the archipelagic State "shall refer proposals to the competent international organization, i.e., the IMO, with a view to their adoption." ${ }^{, 72}$ Typically, the technical merits of such proposals are considered by a sub-committee of the IMO's Maritime Safety Committee (MSC) ${ }^{73}$ The IMO does not impose a decision on the archipelagic State, but rather it "may adopt only such lanes and traffic separation schemes as may be agreed with the archipelagic State" and after which the latter "may designate, prescribe or substitute them." 74 This does not mean the archipelagic State has wide latitude. The rules on innocent passage applicable to archipelagic waters further specify that in designating sea lanes and

${ }^{65}$ Archipelagic State means "a State constituted wholly by one or more archipelagoes and may include other islands." Id., art 46. There are rules concerning proportionality of land and area of water captured by the baselines, length of baselines and compliance with configuration of the archipelago. Id., art 47(1)-(3).

${ }^{66}$ Id., art 49(3).

${ }^{67}$ Id., art 52(1).

${ }^{68}$ Id., art 21(1).

${ }^{69}$ E.g., such sea lanes and air routes are to be defined by a series of continuous axis lines from the entry to the exit points of the passage routes. Id., art 53(5) and (6).

${ }^{70}$ Id., art 53(8).

${ }^{71}$ International Convention for the Safety of Life at Sea, 1974, 1 November 1974, 1184 UNTS 2 [hereafter cited as "SOLAS"]. For a consolidated version of this instrument including all amendments, see IMO, SOLAS Consolidated Edition 2014 (London: IMO Publishing, 2014).

${ }^{72}$ LOS Convention, see n. 5 above, art 53(9).

${ }^{73}$ Formerly considered by the Sub-Committee on Safety of Navigation (NAV), following recent committee reorganization in the IMO technical consideration of such proposals is now the responsibility of the Sub-Committee on Navigation, Communications and Search and Rescue.

${ }^{74}$ LOS Convention, see n. 5 above, art 53(9). 
traffic separation schemes the archipelagic State "shall take into account ... the recommendations of the competent international organization."75

The archipelagic State has a duty to give due publicity to the sea lanes and traffic separation schemes as prescribed on navigation charts. ${ }^{76}$ The coastal State may suspend innocent passage in specific areas for the protection of its security, but only temporarily and without discrimination. ${ }^{77}$ It is unclear whether security includes energy security concerns or simply military defence. Hypothetically, a State whose OWF is threatened by a vessel in distress or a marine casualty posing a risk of pollution may have no alternative course of action than responding to the threat by suspending passage in the interests of safety while responding to an emergency.

These procedures ensure that that there is an enforceable right against foreign ships which do not respect the rules for archipelagic sea lanes passage. ${ }^{78}$ In the interests of maritime safety, it is advisable for an archipelagic State planning OWFs in its archipelagic waters to also establish sea lanes and traffic separation schemes to regulate traffic, as otherwise, in the absence of such sea lanes and schemes, the archipelagic sea lanes passage may be exercised through any routes normally used for navigation. ${ }^{79}$

\subsubsection{Territorial sea}

Clearly the coastal State has the right to establish OWFs in the territorial sea. However, while the coastal State enjoys sovereignty in the territorial sea, it is subject to the right of innocent passage for international shipping traversing those waters continuously and expeditiously and with no intent of calling into that coastal State's ports. ${ }^{80}$

As in the case of archipelagic sea lanes passage, innocent passage through the territorial sea may be regulated by the coastal State. Similarly to archipelagic waters, the power to regulate is particularly valuable in support of OWFs because regulation may concern maritime safety, protection of installations and facilities and cables. ${ }^{81}$ Regulation must be non-discriminatory and has to operate within the parameters of international rules and standards. ${ }^{82}$ It may establish sea lanes and separation schemes in the interests of navigation safety. Again, as in the case of archipelagic waters, the coastal State is required to take into account IMO recommendations when designating sea lanes and traffic separation schemes, clearly implying that it has to proceed through the IMO. ${ }^{83}$ There is a duty to indicate sea lanes and schemes on charts and to give them due

\footnotetext{
${ }^{75}$ Id., art 22(3)(a).

${ }^{76}$ Id., art 53(10).

${ }^{77}$ Id., art 52(2).

${ }^{78}$ Foreign vessels have a duty to respect sea lanes and traffic separation schemes in archipelagic waters adopted in accordance with these procedures. Id., art 53(11).

${ }^{79} \mathrm{Id}$. , art 53(12).

${ }^{80} \mathrm{Id}$., art 18. Innocent passage is defined in art 19. It has a duty not to hamper passage, except in accordance with the LOS Convention. Id., art 24(1).

${ }^{81}$ Id., art 21(1)(a)-(c).

${ }^{82} \mathrm{Id}$., arts 21(2) and 24(1)(b).

${ }^{83}$ Id., arts 22(2)-(3).
} 
publicity. ${ }^{84}$ Particularly in European Union (EU) waters, the coastal State will also be expected to integrate sea lanes and schemes into its marine spatial plan as required under EU regulation. ${ }^{85}$ The LOS Convention provides the coastal State with the right to suspend innocent passage in specified areas and on a temporary basis for security reasons. ${ }^{86}$ The same comment regarding energy security made earlier applies here.

\subsubsection{Straits used for international navigation}

A further nuanced balance between coastal State and international navigation rights is to be found in the regime for straits used for international navigation between the high seas or an EEZ and similar areas beyond the strait. ${ }^{87}$ Such straits are subject to the right of transit passage, namely navigation for continuous and expeditious transit through the strait. ${ }^{88} \mathrm{As}$ in the territorial sea, strait States may regulate transit passage with regard to maritime safety in a non-discriminatory manner. ${ }^{89}$ This power does not extend to the protection of installations, facilities and cables. It is unclear why this is the case, especially where straits may extend to $24 \mathrm{M}$, although in practice the constricted geography of narrower straits militates against using such spaces for space intensive OWFs. Perhaps reinforcement of the expectation that such straits must always remain open for navigation justifies the inability of the strait State to suspend transit passage, ${ }^{90}$ in contrast to archipelagic sea lanes passage and innocent passage. In the interest of maritime safety, strait States may designate sea lanes and traffic separation schemes, which must conform to generally accepted international rules and proposals for which must be submitted to the IMO for adoption prior to actual designation. ${ }^{91}$ Publicity requirements apply as in the case of similar measures in archipelagic waters and the territorial sea. ${ }^{92}$

\subsection{OWFs in ocean areas subject to functional jurisdiction}

In addition to national maritime zones subject to sovereignty, the coastal State enjoys a range of other sovereign rights and jurisdictions for particular purposes, referred to as functional jurisdictions. They consist of the $24 \mathrm{M}$ contiguous zone, 200M EEZ, and continental shelf whose outer limits may be defined in various ways. Coastal State functional jurisdiction is again

\footnotetext{
${ }^{84} \mathrm{Id}$., art 22(4). The coastal State also has duties to publicise its laws and regulations and dangers to navigation it is aware of. Id., respectively arts 21(3) and 24(2).

${ }^{85}$ Directive 2014/89/EU of the European Parliament and of the Council of 23 July 2014 establishing a framework for maritime spatial planning, L 257/135. See also Directive 2002/59/EC of the European Parliament and of the Council of 27 June 2002 establishing a Community vessel traffic monitoring and information system and repealing Council Directive 93/75/EEC.

${ }^{86}$ LOS Convention, see n. 5 above, art 25(3).

${ }^{87}$ Id., art 37. Not all waters in a strait are covered by this regime (e.g., internal waters, unless they had a different status prior to enclosure by straight baselines; waters beyond the territorial sea; straits governed by other longstanding agreements). Id., art 35.

${ }^{88}$ Id., art 38(2). Transit passage includes navigation for the purpose of entering or departing from a State bordering the strait. Id.

${ }^{89}$ Id., art 42.

${ }^{90}$ Id., art 45(2).

${ }^{91}$ Id., art 41(1)-(4).

92 Id., arts 41(6) and 42(3).
} 
counterbalanced by international navigation rights and their significance for OWFs is explained next.

\subsubsection{Contiguous zone}

The contiguous zone is the least relevant area where functional jurisdiction is exercised for OWF purposes. The zone, which technically extends for an additional 12M beyond the outer limit of the territorial sea (hence $24 \mathrm{M}$ ) consists of particular preventative and enforcement powers with regard to customs, fiscal, immigration and sanitary laws, and specifically for the purposes of preventing the infringement and enforcement of violations of such laws within its territory or territorial sea. ${ }^{93}$ The locus of actual potential violations of the laws concerned is not likely an issue for OWFs.

\subsubsection{Exclusive economic zone (EEZ)}

While most OWFs are located in the relatively shallow territorial sea, there is a growing trend to develop OWFs further seaward into the EEZ. Driving this trend are advances in substructure design and submarine cable technology enabling OWF development in deeper waters and at greater distances from shore. Moreover, the larger size of the EEZ accommodates the increasing scale and area of modern OWFs and avoids the congestion associated with inshore areas. A good example is Belgium, whose short coastline generates a narrow territorial sea in congested waters, necessitating the utilization of a distant offshore location for a sizeable OWF. ${ }^{94}$

The EEZ may not extend beyond $200 \mathrm{M}$ from the baselines of the territorial sea, ${ }^{95}$ effectively encompassing $188 \mathrm{M}$ of sovereign rights and jurisdictions beyond the territorial sea. Within the zone proper the coastal State is endowed with sovereign rights and jurisdictions necessary for OWF purposes. Sovereign rights are exclusive to the coastal State and include activities for "the economic exploitation and exploration of the zone, such as the production of energy from the water, currents and winds." ${ }^{96}$ It should be noted that the coastal State exercise of its rights with regard to the seabed and subsoil of the EEZ are to be exercised in accordance with the provisions for the continental shelf in Part VI. ${ }^{97}$ The purpose of the OWF is not the exploration and exploitation of the resources of the sea bed and subsoil, and any activity related to seabed and subsoil may be described as incidental to the principal purpose of extracting energy from the wind. The purpose of the rights set out in Part VI concern the exploration and exploitation of the nonliving resources of the continental shelf, although other rights with regard to environmental jurisdiction and marine scientific research are set out elsewhere in the Convention. ${ }^{98}$

\footnotetext{
${ }^{93}$ Id., art 33.

94 As described in Establishment of an Area To Be Avoided, Submitted by Belgium, IMO Doc. NAV 57/3/3, 25 February 2011 [hereafter cited as "Belgium ATBA Submission"].

${ }^{95}$ LOS Convention, see n. 5 above, art 57.

${ }^{96} \mathrm{Id} .$, art 56(1)(a).

${ }^{97}$ Id., art 56(3).

${ }^{98}$ Id., arts 208, 214 and 246.
} 
Accompanying the sovereign right with regard to the production of energy, the coastal State also has jurisdiction over "the establishment and use of artificial islands, installations and structures" in the EEZ, ${ }^{99}$ and the actual establishment of which is an exclusive right of the coastal State. ${ }^{100}$ This is a key power for designating areas and actual establishment of OWFs and their infrastructure. Thus the coastal State's jurisdictional rights with regard to OWFs designation, establishment and operation in the EEZ are clear, and they include a due regard duty towards the rights and duties of other States. ${ }^{101}$ Such rights of other States include international navigation and overflight, laying of submarine cables and pipelines, and other international lawful uses related to such uses. ${ }^{102}$ An OWF could potentially affect an international navigation route and possibly overlap with a previously laid power or communications cable of another State, a right protected in both Parts V and VI. ${ }^{103}$ In laying its own cables to support an OWF, the coastal State has a due regard duty to cables and pipelines already in position. ${ }^{104}$

The LOS Convention rules regarding artificial islands, installations and structures in the EEZ are critical for OWFs. They perform major functions in (a) further clarifying the allocation of rights and their extent and (b) providing a framework for conflict avoidance. As indicated, the coastal State enjoys exclusive jurisdiction to construct, authorize and regulate the construction, operation and use of installations and structures for the purposes, inter alia, for the production of wind energy. It has a similarly exclusive power to regulate installations and structures which may interfere with the exercise of its rights. ${ }^{105}$ For example, other States undertaking marine scientific research and employing installations and structures in the coastal State's EEZ would be subject to such power. A potential constraint for the coastal State is that artificial islands, installations and structures "may not be established where interference may be caused to the use of recognized sea lanes essential to international navigation."106 It has been seen that OWF arrays and their infrastructure have the capacity of occupying large ocean expanses. It is interesting to note that the Convention refrains from using the peremptory verbs "shall" or "must". This provision needs to be interpreted against a standard of reasonableness in the balancing of respective interests. ${ }^{107}$ While "interference" can be interpreted broadly, the use of the verb "may" and reference to "essential" suggest that the coastal State has leeway as long as the location of the OWF does not have the functional effect of denying or substantially impairing international navigation, for example by diverting traffic at considerable additional user cost and delay.

Artificial islands, installations and structures potentially interact with other ocean uses. They need to be marked so that other ocean users are warned of their presence. ${ }^{108}$ If they fall into

\footnotetext{
${ }^{99}$ Id., art 56(1)(b)(i). Other jurisdictions include marine scientific research and protection and preservation of the marine environment. Id., art 56(1)(b)(ii)-(iii).

${ }^{100}$ Id., art 60(1).

${ }^{101}$ Id., art 56(2).

102 Id., art 58(1).

${ }^{103}$ Id., arts 58 and 79.

${ }^{104}$ Id., art 79(5).

105 Id., art 60(1)(b).

${ }^{106}$ Id., art 60(7).

107 The LOS Convention in fact empowers the coastal State to establish "reasonable" safety zones and that they be "reasonably related" to their nature and function. Id., art 60(4)-(5).

${ }^{108}$ Id., art 60(3).
} 
disuse or are abandoned, they are expected to be dismantled in accordance with generally accepted international standards adopted by the competent international organization. ${ }^{109}$ In practice, lessons from the oil and gas industry indicate that the decommissioning and dismantling process can be complex and controversial. ${ }^{110}$ With large structures, such as gravity-based platforms, total removal may not always be feasible. The Convention anticipates such difficulties and requires that appropriate publicity "shall be given to the depth, position and dimensions of any installations or structures not entirely removed." 111

Artificial islands, installations and structures may also be accompanied by safety zones in the interests of their safety as well as navigation safety. The Convention permits a radius of up to $500 \mathrm{~m}$ from the outer edge, but this can smaller, or be larger if they are justified by generally accepted international standards authorized by the competent international organization. ${ }^{112}$ In practice, defining the outer edge may be interpreted with expansive effect, such as where installations are tethered with lengthy anchor systems or form complex systems of multiple surface and sub-surface structures. It is understandable that a floating installation's anchors should not be disturbed and, where safety practice so dictates, this may well justify using them as reference points to determine the safety zone radius. In this regard a matter not fully addressed by the Convention is submerged power cable grids. The Convention does not permit safety zones around submarine cables. However, the Convention was adopted before the advent of OWFs and their complex subsurface infrastructure. The principal safety concern here is not surface navigation, but rather any fishing activity that involves bottom trawling, and it is common sense to protect both the power cables and surface users from potential accidents. Surely the standard of reasonableness should apply to support safety exclusion zones in the vicinity of cables. ${ }^{113}$ Whatever the breadth of safety zones, due notice is to be given of their extent. ${ }^{114}$

In summary, the coastal State's freedom to allocate EEZ space for OWF development is subject to certain constraints.

${ }^{109} \mathrm{Id}$.

110 The most salient example of the controversy generated by decommissioning offshore oil and gas installations is provided by the international protest which erupted in the wake of Shell's 1995 proposal to decommission the Brent Spar installation through deep water offshore disposal, a proposal arrived at following an extensive consultation process. See Shell, "Brent Spar Dossier," < http://www.shell.co.uk/sustainability/decommissioning/brent-spar-dossier.html>.

${ }^{111}$ LOS Convention, see n. 5 above, art 60(3).

112 Id., art 60(5).

${ }^{113}$ Id., references to reasonableness in art 60(4) and (5). The issue of safety zones for cables was addressed in The Crown Estate, Submarine Cables and Offshore renewable Energy Installations: Proximity Study (The Crown Estate, 2012), online: <http://www.thecrownestate.co.uk/media/5708/submarine-cables-and-offshore-renewable-energyinstallations-proximity-study.pdf $>$. Danish legislation provides for an automatic 200m safety zone around pipelines and cables. Id., p. 55. This report noted that safety zones would be beneficial for both wind farm developer and cable owner. Id., p. 79. Isle of Man legislation prescribes a safety exclusion zone of $250 \mathrm{~m}$ around cables. Safety zone breach without prior authorisation is a criminal offence. Id., 90.

${ }^{114}$ LOS Convention, see n. 5 above, art 60(5). 


\subsubsection{Continental shelf}

The LOS Convention permits coastal States a continental shelf with a limit of 200M (referred to as inner continental shelf for discussion purposes) even where the outer edge of the continental margin does not extend to that distance. ${ }^{115}$ The consequence is that this distance-based shelf entitlement and the 200M EEZ (when declared) overlap. While the LOS Convention provides that "the rights over the continental shelf do not depend on occupation, effective or notional, or on any express proclamation", ${ }^{116}$ there is no similar provision attesting to the innateness of rights to the EEZ, with the consequence that the coastal State may exercise its entitlement to the zone through an express declaratory act. ${ }^{117}$ As noted earlier, the EEZ rights with regard to the seabed and subsoil are to be exercised in accordance with Part VI on the continental shelf. In practice, because the purpose of an OWF is wind extraction and not seabed resource extraction (but entailing subsidiary use of the sea bed and subsoil), the coastal State's power to establish OWFs on the inner continental shelf where an EEZ has been declared does not pose issues, other than the due regard duty and rights of existing pipelines and cables discussed earlier.

More complex legal considerations arise where an EEZ has not been declared or where there is an outer continental shelf. LOS Convention Article 76 sets out scientific criteria to determine appurtenance and outer limits of the continental margin for continental shelves that extend beyond 200M (referred to as outer continental shelf for discussion purposes). ${ }^{118}$ At this time there may be little concern over the establishment of OWFs on the outer continental shelf, but in the future technological development might permit such distant offshore locations for OWFs.

The differences between the EEZ and continental shelf regimes will be even more evident because on the outer continental shelf production of energy from the wind is not included among the exclusive rights assigned to the coastal State. ${ }^{119}$ The coastal State's right to the continental shelf consists of sovereign rights to explore and exploit its natural resources, ${ }^{120}$ and these are defined as non-living resources of the sea bed and subsoil, including sedentary species as the only living resources included in the shelf's sovereign rights. ${ }^{121}$ In comparison, the sovereign rights over the seabed and subsoil in the EEZ are not as limited. ${ }^{122}$ Moreover, the list of freedoms of the

\footnotetext{
115 Id., art 76(1).

116 Id., art 77(3).

117 See the detailed discussion on this issue in D. Attard, The Exclusive Economic Zone in International Law (Oxford: Clarendon press, 1987), pp. 54-61. Attard further discusses the doctrines underlying the differences and relationship between the EEZ and continental shelf. Doctrinal discussion on the "parallelism" between the two zones is also conducted by B. Kwiatkowska, The 200 Mile Exclusive Economic Zone in the New Law of the Sea (Dordrect: Martinus Nijhoff, 1989), pp. 6-19.

${ }^{118}$ LOS Convention, see n. 5 above, art 76(1). The criteria and procedures to be satisfied for the outer continental shelf are set out in the rest of the article.

${ }^{119}$ Id., art 77. The coastal State's exclusive sovereign rights relate to exploration and exploitation of mineral and other non-living resources of the seabed and subsoil.

${ }^{120}$ Id., art 77(1).

${ }^{121}$ Id., art 77(4).

${ }^{122}$ For example in the EEZ the seabed may be used to emplace installations to generate power from ocean currents by virtue of art 56(1)(a), Id. In comparison, the continental shelf's natural resources are mineral and non-living of the
} 
high sea set out in Convention are not exclusive; rather, the list is "inclusive" because the freedom of the high seas is expressly stated as comprising the stated freedoms, "inter alia." 23 An interesting argument to explore is whether this inclusive statement on the freedom of the high seas paves the way for including the production of energy. ${ }^{124}$ While this topic is beyond the focus of this article, the doctrine of the high sea at this time appears to be sufficiently broad to potentially accommodate new uses of the high seas that may become possible in the future as a result of technological advancements and commercial feasibility.

The superjacent waters and airspace on the outer continental shelf are effectively high seas. The rights of the coastal State do not affect their status. ${ }^{125}$ On the contrary, in exercising its rights to the outer continental shelf (i.e., with regard to the non-living natural resources of the seabed and subsoil), the coastal State's activities "must not infringe or result in unjustifiable interference with navigation and other rights and freedoms of other States ..."126 Thus, while LOS Convention Part VII, concerning the regime of the high seas, provides that its provisions do not apply to internal waters, archipelagic waters, territorial seas and EEZs, they apply to all other ocean spaces including the waters superjacent to continental shelves. ${ }^{127}$ The freedoms of the high seas include navigation (without restriction), overflight (without restriction), laying of submarine cables and pipelines (subject to Part VI on the continental shelf), construction of artificial islands and installations (subject to Part VI), freedom of fishing (subject to conditions in Part VII, section 2), and freedom of scientific research (subject to Parts VI and VIII), ${ }^{128}$ all of which are subject to a due regard duty to the interests of other States. ${ }^{129}$ Of particular note is the "freedom" to construct artificial islands and installations on the continental shelf, subject to restrictions, which does not exist in the EEZ. The particular attributes of the outer continental shelf are further highlighted in Article 246(6) with regard to marine scientific research, where the Convention does not provide the coastal State with the same degree of discretion to withhold consent to requests to conduct research by other States. ${ }^{130}$

The coastal State still enjoys considerable powers with regard to artificial islands, installations and structures. In this regard the EEZ Article 60 rules apply to the continental shelf by virtue or Article 80, but "mutatis mutandis". ${ }^{131}$ The history of the negotiation of Article 80 and related provisions provides some clues, but leaves the scope of the adapting change unclear. The

seabed and subsoil: id., art 77(4). Hence continental shelf rights essentially relate to "resource extraction" rather than "the production of energy from the water, currents and winds": Id., art 56(1)(a).

${ }^{123} \mathrm{Id}$., art 87(1). Also relevant is art 78(1) which protects "navigation and other rights and freedoms of other States as provided in this Convention" from infringement by the coastal State.

${ }^{124}$ D.P. O'Connell wrote that "The concept of the freedom of the high seas is neither absolute nor static: it embodies the balance of jurisdictional functions among States which at any time best serve the community of nations, and its content is subject to constant modification as that community adjusts itself to the solution of new problems." The International Law of the Sea vol II (Oxford: Clarendon Press, 1984), pp. 796-797.

${ }^{125}$ LOS Convention, above note 5, art 78(1).

${ }^{126}$ Id., art 78(2).

${ }^{127}$ Id., art 86.

${ }^{128}$ Id., art 87(1).

${ }^{129}$ Id., art 87(2).

${ }^{130} \mathrm{Id}$., art 246(6).

${ }^{131}$ Id., art 80. 
leading commentary on the Convention concludes that the interpretation given to Article 60 applies to the "Article insofar as they can be applied to the continental shelf" (emphasis added $).{ }^{132}$ The term mutatis mutandis is used in several other provisions of the LOS Convention, in different contexts and similarly with little if any guidance. ${ }^{133}$

Even while taking Article 56(3) into consideration, clearly there are important differences between the EEZ and continental shelf which potentially have a bearing on the interpretation of mutatis mutandis to the continental shelf. The term mutatis mutandis implies that adjustments to Article 60 are necessary to enable the application of the provision's rules to the continental shelf. ${ }^{134}$ Interestingly, while there are general rules of interpretation in the Vienna Convention on the Law of Treaties, 1969 135 , there is no explicit guidance on cross-referencing and incorporating provisions. To date international case law does not provide authoritative guidance on the scope of the term, despite its frequent use for drafting efficiency. ${ }^{136}$ In some contexts the term has been criticized for lack of precision and the possibility of introducing an element of subjectivity. ${ }^{137}$ The literature similarly offers little guidance on the use of the term in international law. ${ }^{138}$

There are potentially alternative modes of interpreting Article 80, as set out in Table 2 . For the purposes of this discussion the key provision is the first sub-article (i.e., Article 60(1)), which sets out the scope of jurisdiction over artificial islands, installations and structures. The first column sets out the pertinent rules for EEZ purposes. The second column provides a first variation where mutatis mutandis is narrowly interpreted as a purely textual exercise, i.e., (a) the term

132 S.N. Nandan \& S. Rosenne, vol. eds., United Nations Convention on the Law of the Sea: A Commentary vol II (Dordrecht: Martinus Nijhoff Publishers, 1993), p. 926.

${ }^{133}$ LOS Convention, see n. 5 above, arts 1, 54, 110(4), 111(2) \& (6), 162(2)(k), 233, 285, Annex VII art 13 and Annex VII art 4.

${ }^{134}$ Black's Law Dictionary 9d defines mutatis mutandis as "With the necessary changes in points of detail, meaning that matters or things are generally the same, but to be altered when necessary, as to names, offices, and the like."

135 Convention on the Law of Treaties, Vienna, 23 May 1969, UN Doc. A/ Conf.39/27, 1155 UNTS 331, arts 31-33.

136 One particularly interesting case is United States - Sunset Review of Anti-dumping Duties on Corrosion-resistant Carbon Steel Flat Products from Japan, AB-2003-5, Panel Report, WT/DS244/R, 14 August 2003. Japan was of the view that the term meant application of all the provisions of one article to another. The US view was that the term meant with necessary changes or changes as appropriate. The Panel held that "... the use of the term 'mutatis mutandis' demonstrates that the drafters foresaw that certain provisions of Article 12 could not be applied, at all, or at the very least not in an identical manner, in the case of sunset reviews." para. 7.33. The Appellate Body, while reversing aspects of the Panel Report, did not revisit this understanding of mutatis mutandis. Report of the Appellate Body, WT/DS244/R, 15 December 2003.

${ }^{137}$ For example see the $\mathrm{S}$. Rosenne comments during discussions on draft articles on the relations between States and international organizations. Yearbook of the International Law Commission, vol 1 (1970), Summary records of the twenty-second session 4 May-10 July 1970, p. 29.

${ }^{138}$ An observation also made in a trade law context. See J.D. Barbosa, "Untangling the mutatis mutandis principle in Free Trade Agreements: Using the WTO to understand FTAs," Society of International Economic Law, Third Biennial Global Conference, 12-14 July 2012, Online Proceedings, Working Paper No. 2012/28, at 3, available online: <http://papers.ssrn.com/sol3/papers.cfm?abstract_id=2091497>. 
continental shelf replaces EEZ, (b) Article 77 replaces the reference to Article 56, and (c) "on the shelf" replaces "in the zone." The text in (b) is inserted because it cannot have been the intention of the negotiators of the Convention to extend all of Article 56 into the continental shelf when Article 56(3), which subjects the sea bed and subsoil to the continental shelf, is taken into consideration. The third column sets out a second variation with a proposed functional and contextual interpretation of mutatis mutandis to accompany the textual changes in the first variant. The functional and contextual dimensions demand a more in-depth explanation.

Table 2: Potential Article 80 mutatis mutandis impacts on Article 60

\begin{tabular}{|c|c|c|}
\hline \multirow{2}{*}{$\begin{array}{l}\text { Article } 60 \\
\text { Artificial islands, installations and } \\
\text { structures in the exclusive economic } \\
\text { zone }\end{array}$} & \multicolumn{2}{|c|}{$\begin{array}{l}\text { Mutatis mutandis effect of Article } 80 \\
\text { Artificial islands, installations and structures on the continental shelf }\end{array}$} \\
\hline & $\begin{array}{l}\text { Variation } 1 \\
\text { (Textual) }\end{array}$ & $\begin{array}{l}\text { Variation } 2 \\
\text { (Textual, functional \& contextual) }\end{array}$ \\
\hline $\begin{array}{l}\text { 1. In the exclusive economic zone, } \\
\text { the coastal State shall have the } \\
\text { exclusive right to construct and to } \\
\text { authorize and regulate the } \\
\text { construction, operation and use of: } \\
\text { (a) artificial islands; } \\
\text { (b) installations and structures for } \\
\text { the purposes provided for in article } \\
56 \text { and other economic purposes; } \\
\text { (c) installations and structures which } \\
\text { may interfere with the exercise of } \\
\text { the rights of the coastal State in the } \\
\text { zone. }\end{array}$ & $\begin{array}{l}\text { 1. On the continental shelf, the } \\
\text { coastal State shall have the exclusive } \\
\text { right to construct and to authorize } \\
\text { and regulate the construction, } \\
\text { operation and use of: } \\
\text { (a) artificial islands; } \\
\text { (b) installations and structures for } \\
\text { the purposes provided for in article } \\
\underline{77} \text { and other economic purposes; } \\
\text { (c) installations and structures which } \\
\text { may interfere with the exercise of } \\
\text { the rights of the coastal State on the } \\
\text { shelf. }\end{array}$ & $\begin{array}{l}\text { 1. Subject to Article } 87(1) \text {, on the } \\
\text { continental shelf, the coastal State } \\
\text { shall have the exclusive right to } \\
\text { construct and to authorize and } \\
\text { regulate the construction, operation } \\
\text { and use of: } \\
\text { (a) artificial islands; } \\
\text { (b) installations and structures for } \\
\text { the purposes provided for in article } \\
77 \text { and other economic purposes; } \\
\text { (c) installations and structures which } \\
\text { may interfere with the exercise of } \\
\text { the rights of the coastal State on the } \\
\text { shelf. }\end{array}$ \\
\hline
\end{tabular}

The functional dimension Article 60-80 duet refers to the actual functional powers conferred in Article 77 (by virtue of Article 56(3)). Article 77 does not include sovereign rights for "other economic purposes". The proposition here is that the negotiators of the Convention intended to set out the coastal State's rights to the continental shelf in Article 77 and that Article 80 was specifically intended to service those rights only. Thus, the coastal State's exclusive right to construct and authorize the construction, operation and use of artificial islands, installations and structures is limited to the rights it has on the continental shelf.

The contextual dimension approaches the duet with reference to their position and relationship to the Convention as a whole, and in particular the freedoms in Article 87. Clearly, because of Article 87(1) high seas freedom to construct artificial islands and other installations (note that "structures" are not included in this provision), the Article 60 "exclusive right to construct and to authorize and regulate the construction, operation and use of" the same cannot be 
exclusive with regard to the continental shelf. Articles 56(3), 60(1), 80 and 87 have to be interpreted to produce a harmonious interface.

\subsection{OWFs in ocean areas beyond national jurisdiction}

It is conceivable that the high seas might also one day be the locus of OWF installations, structures and related infrastructure, such as submarine cables, established by States by virtue of the freedoms they enjoy under Article 87. Clearly they have far less opportunity to influence the ocean uses of other user States. The Convention is silent with regard to the rules applicable to artificial islands, installations and structures on the high seas, other than for the purpose of activities in the international seabed area. ${ }^{139}$ If ships and installations are utilized for the production of wind energy, the State concerned will have the rights and duties of a flag State and enjoy exclusive jurisdiction over its vessels. ${ }^{140}$ States have a duty to exercise the freedoms of the high seas with due regard to the interests of other States as they exercise their freedoms and also with regard to activities in the international seabed area. ${ }^{141}$

\section{MARITIME REGULATION}

\subsection{MSP framework}

At the outset of this article marine spatial planning was identified as playing an important role in the process of mutual accommodation of OWFs and international navigation rights. While sea use planning and management practices have been in place in some States for decades, it is relatively recent that integrated planning and management for ocean space have received endorsement as good practices backed by national and regional legislation. ${ }^{142}$ Recent EU legislation introducing marine spatial planning as a required practice in Member States and defining it as "a process by which the relevant Member State's authorities analyse and organise human activities in marine areas to achieve ecological, economic and social objectives." 143 Douvere and Ehler describe marine spatial management as aiming to provide "a mechanism for a strategic and integrated planbased approach for marine management that makes it possible to look at the 'bigger picture' and to manage current and potentially conflicting uses to reduce the cumulative effects of human activities, and to deliver marine protection." "144 The authors provide several examples where MSP has been operationalized, mostly in EU Member States and some of which (in particular Belgium, Germany, Netherlands and United Kingdom) have had to accommodate offshore windfarms in the context of complex multiple use ocean environments and in semi-enclosed seas. ${ }^{145}$

\footnotetext{
${ }^{139}$ LOS Convention, see n. 5 above, art 147(2).

${ }^{140}$ Id., art 94.

${ }^{141} \mathrm{Id}$., art 87(2). See also art 112 which applies the duty of due regard with regard to existing pipelines and cables set out in art 79(5).

${ }^{142}$ Canada was one of the first States to legislate integrated ocean management. See Oceans Act, SC 1996, c 31, Part II, in particular ss. 30(b), 31 and 32 .

${ }^{143}$ Directive 2014/89/EU of the European Parliament and of the Council of 23 July 2014 establishing a framework for maritime spatial planning, L 257/135, art 3(2).

${ }^{144}$ Douvere \& Ehler, above note 4, p. 7.

145 Id., p. 11-16.
} 
While MSP appears to be gaining ground as an integrative framework for ocean development within national jurisdiction, for effective management it demands the utilization of a wide range of regulatory and administrative tools and measures, which for OWF purposes include licensing of use area, risk assessment, routeing measures, appropriate markings, and maritime safety notices to shipping and mariners. Our main concern is with maritime regulatory tools which, while developed in the context of shipping, also provide the tools within (or without) an MSP framework because they provide maritime safety measures that apply to virtually all commercial and most recreational ocean uses.

\subsection{IMO tools and measures}

The tools used in an MSP process to regulate maritime safety are often based on international rules and standards adopted by or under the auspices of the IMO as mandated in the LOS Convention. The IMO adopts such rules and standards either under an international maritime convention or by virtue of its mandate in its constitutive instrument. ${ }^{146}$ In addition to international conventions, the IMO promotes good practices through a range of other non-binding instruments, such as codes and guidelines adopted by resolution and intended to facilitate and assist uniform practices without necessarily casting them in peremptory forms. ${ }^{147}$

The key instrument is the International Convention for the Safety of Life at Sea, 1974 (SOLAS) which consists of a framework for the adoption of international rules and standards concerning maritime safety, primarily the construction, equipping and crewing of ships. ${ }^{148}$ The regulatory teeth of SOLAS are fourteen chapters of regulations which are also enforced through port State control. States interested in OWF development have to consider the rules concerning construction, equipping and operation of offshore service vessels (OSVs). While not a central concern of this article, the regulation of OSVs and technical workers to support OWF construction and maintenance are under development. ${ }^{149}$ Much of SOLAS is primarily aimed at States that operate ships, although Chapter $\mathrm{V}$ also includes provisions concerning the administration of navigation of specific interest to coastal States planning and operating OWFs and their expectations of ships navigating in the vicinity of their OWFs. These provisions include: communication of information on dangers to navigation (Regulation 4); hydrographic services (Regulation 9); routeing measures (Regulation 10); ship reporting systems (Regulation 11); vessel

146 Convention on the International Maritime Organization. Geneva, 6 March 1948, 289 UNTS 3. An example is the IMO mandate to designate PSSAs, which is not a power exercised under SOLAS, but rather under the IMO Convention. However, routeing measures in a PSSA are adopted under SOLAS.

${ }^{147}$ E.g Guidelines on Places of Refuge for Ships in Need of Assistance, IMO Assembly Resolution A.949(23), 5 December 2003, IMO Doc. A 23/Res.949, 5 March 2004.

148 SOLAS, see n. 71 above.

${ }^{149}$ Current regulations of relevance for design and construction of OWF special purpose ships and installations are: Code for the Construction and Equipment of Mobile Offshore Drilling Units, 1989; Guidelines for the Design \& Construction of Offshore Supply Vessels, 2006; Code of Safety for Special Purpose Ships, 2008. The IMO is in the process of developing codes for OWF construction vessels and support craft. See IMO, Sub-Committee on Ship Design and Equipment (DE), 56 ${ }^{\text {th }}$ Session, $13-17$ February 2012, Need for Guidance on application of regulations for OWFCV and OWFSC agreed, available http://www.imo.org/MediaCentre/MeetingSummaries/DE/Pages/DE-56th-session.aspx>. 
traffic services (VTS) (Regulation 12); establishment and operation of navigation aids (Regulation 13); nautical charts (Regulation 27); life-saving signals to be used by ships, aircraft and persons in distress (Regulation 29); danger messages (Regulation 31); and safe navigation and avoidance of dangerous situations (Regulation 34). Aspects of some of the key rules are discussed next with reference to the needs of OWFs.

The IMO is the only international organization having the mandate to develop rules and guidelines for ships' routeing systems and to which States submit proposals for such systems in accordance with the Organization's guidelines. ${ }^{150}$ The key guidelines are the General Provisions on Ships' Routeing and related guidance notes. ${ }^{151}$ As will be seen in the discussion below on the accommodation process, Regulation 10 is proving to be a critical tool for MSP purposes generally and particularly for accommodating OWFs in heavily used marine environments. A routeing system is defined as "[Any system of one or more routes or routeing measures aimed at reducing the risk of casualties; it includes traffic separation schemes, two-way routes, recommended tracks, areas to be avoided, inshore traffic zones, roundabouts, precautionary areas and deep water routes." 152

The purpose of routeing is to improve navigation safety in areas where there is dense or converging traffic and where navigational freedom is constrained by restricted sea-room, obstructions, bathymetry and meteorological conditions. ${ }^{153}$ These are all factors of direct concern to OWFs. While the safety of OWFs and adjacent traffic are not explicitly mentioned as justifying routeing measures, the objective of "the routeing system will depend upon the particular hazardous circumstances which it is intended to alleviate." 154 In general, States are recommended not to establish petroleum and other installations and structures within IMO routeing systems or at the entrance or exit points and if permanent installations need to be established in a TSS, the coastal State is recommended to propose amendments to the scheme to the Organization. ${ }^{155}$ States are expected to ensure that development of the EEZ and continental shelf "does not seriously obstruct sea approaches and shipping routes." 156 Although these recommendations were originally developed with petroleum installations in mind, they would serve to guide similar concerns with OWFs.

Effectively, when OWFs interact with navigation in a manner that requires management intervention, the appropriate procedure requires submission of routeing proposals to the IMO. However, "[T]he selection and development of routeing systems is primarily the responsibility of

${ }^{150}$ SOLAS, see $\mathrm{n} .71$ above, Chap V, reg 10(2).

${ }^{151}$ General Provisions on Ships' Routeing, IMO Doc. Resolution A.572(14), 20 November 1985 [hereafter cited as "General Provisions"]. Adopted measures are published by the IMO in the loose-leaf Ships' Routeing (London: IMO, 2010), updated periodically. See also Guidance Note on the Preparation of Proposals on Ships Routeing Systems and Ship Reporting Systems, IMO Doc. MSC/Circ.1060, 6 January 2003.

${ }_{152}$ General Provisions, see n. 151 above, reg 2.1.1. Specific methods are set out in Part 4 of the General Provisions.

${ }^{153}$ Id., reg 1.1.

${ }^{154}$ Id., regs $1-2$.

${ }^{155}$ Id., regs 3.10-3.11.

${ }^{156}$ Safety Zones and Safety of Navigation around Offshore Installations and Structures, IMO Doc. Res. A/671(16), 19 October 1989 [hereafter cited as Safety Zone Guidelines]. 
the governments concerned." 157 Routeing systems may be mandatory or recommended and may be directed at all ships, particular categories of ships (e.g., deep draught ships) and ships carrying particular cargoes (e.g., hydrocarbons). ${ }^{158}$ Maritime safety may require beneficial discrimination between ships. Ships targeted by routeing requirements are duty-bound to observe such measures, unless there is a compelling reason not to do so and which must be recorded in the log book. ${ }^{159}$

In general, OWF States, just as any State seeking to regulate for maritime safety, are recommended to submit routeing measures for adoption by the IMO. The obvious benefit (in contrast to proceeding outside the IMO) is the greater likelihood of compliance by flag States when IMO endorsement is received because all States have a duty to adhere to the adopted measures and "shall do everything in their power to secure the appropriate use of ships' routeing systems." ${ }^{160}$ It is conceivable that a State might still prefer not to submit a measure to the IMO for adoption, and may do so for information purposes and for distribution in the IMO, but such a course of action may trigger criticism from peer States. ${ }^{161}$ In any case, States that proceed to adopt routeing measures outside the IMO are still encouraged to take into account the IMO guidelines and criteria for such measures in the interests of general consistency. ${ }^{162}$ All routeing measures and related enforcement action must comply with the LOS Convention, ${ }^{163}$ but an important caveat is that "[N]othing in this regulation nor its associated guidelines and criteria shall prejudice the rights and duties of Governments under international law or the legal regimes of straits used for international navigation and archipelagic sea lanes." "64 This caveat applies also to VTS. ${ }^{165}$ On occasion when a routeing measure has transboundary implications, neighbouring States are encouraged to make a joint submission to the IMO. As will be seen below, this was recently the case for Belgium and The Netherlands, both of which needed routeing measures to accommodate OWFs in the North Sea while sharing affected international navigation routes through their EEZs.

157 Id., reg 3.7 .

${ }^{158}$ In practice these focus on particular navigational areas and have included: traffic separation schemes; deep-water routes; areas to be avoided; a range of other measures (e.g., two-way routes); associated rules and recommendations on navigation; mandatory ship reporting; mandatory routeing systems; mandatory no anchoring areas; and adopted archipelagic sea lanes. See IMO, Ships' Routeing (London: IMO, 2008).

159 SOLAS, see n. 71 above, chap X, reg 10(7).

${ }^{160}$ Id., chap V, reg 10(6).

${ }^{161}$ E.g. Canada's implementation of mandatory reporting requirements in its Arctic waters without seeking prior IMO approval, as distinct from simply informing the IMO and requesting circulation of information among its Members, provoked a strong response from the US. See the following documents: Information on the Mandatory Canadian Ship Reporting System in Canada's Northern Waters (NORDREG), IMO Doc SN.1/Circ.291, 5 October 2010; Northern Canada Vessel Traffic Services Zone Regulations, Submitted by the United States and INTERTANKO, IMO Doc. MSC 88/11/2, 22 September 2010; Comments on document MSC 88/11/2 Submitted by Canada, IMO Doc. MSC 88/11/3, 5 October 2010.

162 SOLAS, see n. 71 above, chap V, reg 10(4).

${ }^{163}$ Id., chap V, reg 10(9).

${ }^{164} \mathrm{Id}$., chap V, reg 10(10). This is reiterated even more expansively in the General Provisions: "Nothing in the general provisions on ships' routeing shall prejudice the provisions of the United Nations Convention on the Law of the Sea (1982) nor the present or future claims and legal views of any State concerning the law of the sea and the nature and extent of coastal and flag State jurisdiction." General Provisions, see n. 151 above, reg 3.16.

165 SOLAS see n. 71 above, chap V, reg 13(5). 
Other Chapter V regulations of particular utility in accommodating OWFs concern vessel traffic services and navigation aids. The VTS may be port or coastal and their function is to "contribute to safety of life at sea, safety and efficiency of navigation and protection of the marine environment, adjacent shore areas, work sites and offshore installations from possible adverse effects of maritime traffic."166 In establishing VTS services, coastal States have to bear in mind that they may be made mandatory only in the territorial sea and are recommended to follow IMO guidelines. ${ }^{167}$ Flag States have a "best endeavours" duty to secure VTS compliance by their ships. ${ }^{168}$ With regard to navigation aids, there is a duty to provide navigation aids as can be justified by maritime traffic and the risks involved, taking into account international recommendations and guidelines, which are largely provided by the International Association of Marine Aids to Navigation and Lighthouse Authorities (IALA). ${ }^{169}$ In its submissions to the IMO for routeing measures between North Texel and Hinder to accommodate, among other, OWF needs, The Netherlands had to address the issue of navigation aids. ${ }^{170}$

As seen earlier, coastal States are expected to establish safety zones in accordance with international standards and for this purpose the IMO adopted the Resolution on Safety Zones and Safety of Navigation around Offshore Installations and Structures, $1989 .{ }^{171}$ While the right to establish safety zones around OWFs is a coastal State right under the LOS Convention, they have the potential of creating congestion for maritime traffic and possibly unnecessarily exclude small vessel traffic. This is especially the case when safety zones exceed 500m radius. In IMO discussions concerning guidelines for safety zones in excess of $500 \mathrm{~m}$, Brazil raised a concern that with the expansion of OWFs and wave energy plants there was danger of unnecessary exclusion of small vessels, generally described as recreational and fishing vessels, from OWF space when they posed little to no threat to themselves or the installations. ${ }^{172}$ A Germanischer Lloyd risk study focusing on vessels less than $24 \mathrm{~m}$ confirmed this. ${ }^{173}$ Rather, larger safety zones may have the effect of pushing small vessels into established shipping lanes for commercial vessels.

Irrespective of the purpose of the offshore installations and structures, the coastal State is recommended to give appropriate notice of their location or intended location, including any changes, by issuing notices to mariners. ${ }^{174}$ The notices should include key information such as breadth and navigational restrictions, including fairways if any. In turn, the operators of such installations and structures should take measures to prevent infractions, such as including "effective lights and sound signals, racons, permanent visual look-out and radar watch, listening and warning vessels on VHF channel 16 or other appropriate radio frequencies" and VTS. ${ }^{175}$ In

\footnotetext{
${ }^{166}$ Id., chap V, reg 12(1).

${ }^{167}$ Id., chap V, reg 12(3). See Guidelines on Vessel Traffic Services, IMO Doc. A.857(20), 3 December 1997.

168 SOLAS, chap V, reg 12(4).

${ }^{169} \mathrm{Id}$., chap V, reg 13.

${ }^{170}$ General introduction to the proposals for new and amended routeing measures off the Coast of the Netherlands between Texel and North Hinder, IMO Doc. NAV 58/3/2, 28 March 2012, 4 and 7.

171 Safety Zone Guidelines, see n. 156 above.

172 Guidelines for Consideration of Requests for Safety Zones Larger than 500 Metres around Artificial Islands, Installations and Structures in the EEZ, IMO Doc. NAV 56/4/2, 4 June 2010.

${ }^{173} \mathrm{Id}$.

${ }^{174}$ Safety Zone Guidelines, see n. 156 above, Annex, para 1.1.

175 Id., Annex, para 1.3.
} 
practice, not all OWFs may be in a position to maintain visual look-out, radar watch and be in a position to communicate with vessels because the wind turbines may be automated and remotely controlled. Nonetheless, there remains the need to give appropriate warnings to traffic in the vicinity through appropriate lighting and other measures recommended by the International Hydrographic Organization (IHO) and IALA. ${ }^{176}$ Vessels navigating in the vicinity are required to navigate with caution, employ safe speed and maintain a proper look-out, as well as using routeing measures for the area. ${ }^{177}$ The Collision Avoidance Regulations would apply to such vessels. ${ }^{178}$ Where there are infringements, the coastal State does not necessarily have the power to take enforcement action against the infringing vessel directly, but rather is expected to notify the flag State of the infringement and providing sufficient detail to enable the latter to take the appropriate action against its ship. ${ }^{179}$ In turn, the flag State is expected to notify the coastal State of the enforcement action taken. ${ }^{180}$ This is in recognition of international navigation rights and the primary jurisdiction of flag States over their ships as set out in the LOS Convention. States have not always followed such recommendations, prompting the IMO to issue reminders to both coastal and flag States. ${ }^{181}$

Finally, pursuing the LOS Convention duty in Article 60 to remove abandoned or disused installations and structures to ensure navigation safety in accordance with international standards, the IMO has developed guidelines setting out such standards for removal, and if removal is not possible or only partial removal is, for appropriate marking with navigation aids and notifications to reduce the hazard to navigation. ${ }^{182}$ Of particular note is that where installations and structures are located in straits used for international navigation, archipelagic sea lanes, deep-draught sea lanes or in or adjacent to routeing schemes they should be removed altogether without exception. ${ }^{183}$ Again, these IMO standards are aimed at providing the necessary balance between States' right to establish and duty to remove offshore installations and structures with international navigation rights.

\subsection{Other tools and measures}

The discussion on IMO tools useful to accommodate OWFs and help manage the interaction between their presence and international navigation referenced appropriate markings, navigation aids and charts. In prescribing such requirements, the IMO relies on the work of other specialized international organizations, in particular the IHO and IALA. The IHO is an intergovernmental organization having among its purposes the coordination of the activities of national hydrographic

176 This includes provision of notice through charts and other nautical publications of permanent features such as bottom structures and prohibited areas, in addition to the installations and structures themselves. Submarine cables are not expressly mentioned but they would be included as a permanent bottom obstruction. Id., Annex, para 5.

${ }^{177}$ Id., Annex, para 2.

${ }^{178}$ COLREGS, see n. 38 above.

179 Safety Zone Guidelines, see n. 156 above, Annex, para 3.

${ }^{180}$ Id., Annex, para 3.2.

${ }^{181}$ For example see Guidelines for Safety Zones and Safety of Navigation around Offshore Installations and Structures, IMO Doc., SN.1/Circ.295, 7 December 2010.

${ }^{182}$ Guidelines and Standards for the Removal of Offshore Installations and Structures on the Continental Shelf and in the Exclusive Economic Zone, IMO Doc. Res. A.672(16), 19 October 1989, Annex.

${ }^{183}$ Id., Annex, para 3.7. 
offices and promoting the "greatest possible uniformity in nautical charts and documents." 184 The IHO has adopted regulations for international charts and chart specifications. ${ }^{185}$ Regulations with symbols for annotation of wind turbines (both fixed and floating) and offshore windfarms on medium and large-scale charts have been adopted. ${ }^{186}$ Proper annotation of OWFs on navigation charts is critical for preventing accidents.

While the IALA is not an intergovernmental organization, but rather an international association established under French law, it is a critical industry organization whose recommendations regarding navigation aids are considered as international standards. While it is arguable that IALA, as a non-governmental organization, is not a competent international organization similar to the IMO and other inter-governmental organizations in the LOS Convention, the generally accepted international standards referred to in Article 60 of the Convention must surely include IALA recommendations on aids to navigation. In fact IMO recommendations tend to recommend compliance with IALA recommendations. ${ }^{187}$ Under its Constitution, its aim is to "foster the safe, economic and efficient movement of vessels, through improvement and harmonisation of aids to navigation worldwide and other appropriate means, for the benefit of the maritime community and the protection of the environment." 188 Guided by this purpose, IALA has adopted recommendations on the marking of offshore structures. ${ }^{189}$ National authorities are advised to identify exclusion or safety zones on national nautical charts and publications. ${ }^{190}$ IALA marking recommendations may be adjusted based on risk assessment of various factors, including traffic density and proximity to dangers. Power cables should be trenched to avoid exposure from scouring, sand migration and trawling activities, and where the trench depth is not achieved, additional marking requirements are recommended. Recommendations include rules on lights for surface and air navigation, fog signals and radar beacons. ${ }^{191}$ Specific advice and recommendations for OWFs, including specifically for wind turbines, meteorological mast and offshore transformer/generator, are provided. ${ }^{192}$ For example, the National Authorities are advised that OWFs may affect ship and shore based radar and may cause interference resulting in degradation of radar display. Navigation in close proximity to an OWF may affect a vessel's ability to manoeuvre. Marking lights should be visible from all directions and fog signals should be considered in restricted visibility. The recommendations

\footnotetext{
${ }^{184}$ Convention relative l'Organisation hydrographique internationale (Convention on the International Hydrographic Organization), Monaco, 3 May 1967, 751 UNTS 41 (French text), art 2, online (English text): available online: <http://www.iho.int/mtg_docs/com_wg/ISPWG/Documents/R11_iho_convention.pdf >.

${ }^{185}$ Regulations of the IHO for International Charts (INT) and Chart Specifications of the IHO, ed 4.4.0, September 2013 (Monaco: International Hydrographic Bureau, 2013), available online: <http://www.iho.int/iho_pubs/standard/S-4/S-4_e4.4.0_EN_Sep13.pdf>.

${ }^{186}$ Id., regs B-445.8 (fixed and floating turbines) and B-445.9 (offshore windfarms).

${ }^{187}$ For example Guidelines and Standards for the Removal of Offshore Installations and Structures, see n. 182 above, para 3.3.

${ }^{188}$ Constitution of IALA, art 2, available online: < http://www.iala-aism.org/about/constitution.html>.

${ }^{189}$ IALA Recommendation O-139 on The Marking of Man-Made Offshore Structures Edition 2

December 2013, Edition 1: December 2008.

${ }^{190}$ Id., 8.

${ }^{191}$ Id., 9-10.

192 Id., 11-14.
} 
include specific measures such as identification panels for day and night use, paint colour for structures to ensure visibility.

\section{THE ACCOMMODATION PROCESS}

Much of the experience with OWFs to date has been in semi-enclosed seas where coastal States' ability to generate the full range of maritime zones permissible under the LOS Convention is geographically constrained because of short coastlines and presence of several States. ${ }^{193}$ In particular, the seas around Western Europe are good examples of semi-enclosed seas already subject to multiple and well-established heavy industrial and recreational marine uses, including fishing, oil and gas activities, submarine pipelines and cables, major international shipping routes and ferry services, while needing to accommodate large OWFs. The spatial footprint of OWFs in such constrained geography is substantial. For example as much as $15 \%$ of Germany's EEZ will be covered by OWFs. ${ }^{194}$ It is not surprising that sea use planning and subsequently MSP emerged from practices in these seas out of a fundamental need for orderly and safe ocean uses while protecting the marine environment.

A key tool within the MSP process to accommodate OWFs is formal safety assessment (FSA). ${ }^{195}$ This involves a risk assessment process to determine where, how and under what assumptions and conditions OWFs are to be designated, built and eventually operated. National maritime administrations, such as Germany's Directorate General for Waterways and Shipping, review safety considerations including safety of shipping lanes, collision risk (e.g., one collision per 100 years, design and marking standards, and protection of turbines). ${ }^{196}$ The FSA also helps evaluate marine spatial plans and plays an important role in identifying options for routeing measures with appropriate technical support that will need to be sought through the IMO. ${ }^{197}$ This approach ensures that while the coastal State advances its ocean development interests, it remains cognizant of the imperative to respect and maintain international navigation routes and produce the least impairment while ensuring maritime safety.

The experience of The Netherlands is illustrative of the FSA process leading to the request for routeing measures in international navigation routes. The Netherlands has an ambitious OWF programme for 2015-2019 that anticipates establishing farms with 700MW capacity per year to

\footnotetext{
${ }^{193}$ Enclosed and semi-enclosed sea is defined as "a gulf, basin or sea surrounded by two or more States and connected to another sea or the ocean by a narrow outlet or consisting entirely or primarily of the territorial seas and exclusive economic zones of two or more coastal States." LOS Convention, see n. 5 above, art 122.

${ }^{194}$ R. Long, "Discussion Summary Forum on Offshore Wind Energy: Actors, Legal Instruments and Decision-Making Procedures," in Climate Change and Environmental Hazards Related to Shipping, eds. H-J Koch et al. (Leiden: Martinus Nijhoff, 2013), pp. 227-240 at 236.

195 "FSA is a structured and systematic methodology, aimed at enhancing maritime safety...The FSA is aimed at achieving a balance between the various technical and operational issues, and between maritime safety or protection of the marine environment and costs." Report on the safety assessments for the proposed route structure on the North Sea off the Coast of the Netherlands (Annex), IMO Doc NAV 58/INF.2, 29 March 2012 [hereafter cited as "North Sea Routes FSA'], p. 9.

${ }^{196}$ Long, see n. 194 above, p. 236.

${ }^{197}$ North Sea Routes FSA, see n. 195 above, p. 9.
} 
enable the country to help meet the country's targets for renewable energy sources. ${ }^{198}$ The Dutch maritime space in the North Sea is subject to multiple ocean uses and accounts for 260,000 annual ship movements, more than half of which is traffic for the country's ports. ${ }^{199}$ The Ministry of Infrastructure and the Environment (Rijkswaterstaat) has long developed marine spatial plans to facilitate integrated management of the Dutch sector in North Sea. ${ }^{200}$ More recent emphasis in MSP is on offshore renewable energy development and sand extraction for coastal and flood protection. ${ }^{201}$ In 2010 The Ministry conducted an FSA to identify ideal locations for OWFs and the overall layout with shipping routes and oil and gas installations, producing various options for spatial layouts. This process led to the so-called "IMO Variant" (September 2011) which underwent several iterations. A subsequent FSA (2012) was undertaken as a result of new wind energy priorities producing a new spatial plan for shipping and wind energy farms. ${ }^{202}$ Risk assessment facilitated optimal location, size and layout. Safety of the installations and consideration of safety of other users led to review of marks and lights to be displayed, using IALA recommendations, both for traffic around the OWF and in the farm itself. ${ }^{203}$ When it is desirable to exclude traffic in the farm itself, safety zones of various dimensions may be used, although the effect in enclosed space is to substantially affect other ocean users. It has been suggested that full $500 \mathrm{~m}$ safety zones may not always be necessary or of that breadth, and that during the construction phase or while servicing a wider zone is needed. The possibility of removal of permanent safety zones for small vessel navigation was also considered. ${ }^{204}$ The IMO Variant included nine submissions containing proposals for routeing measures, submitted to the former NAV Subcommittee of the MSC for approval in July 2012. The IMO Variant underwent several iterations and further FSAs. The outcome of the FSA process led to eight separate routeing proposal submissions to the former NAV Sub-committee of the IMO to alter existing and establish new traffic measures at various locations between the North Hinder area and the traffic separation scheme Off Texel. ${ }^{205}$ The rationale was the need to improve navigation safety and safety of offshore oil and gas production platforms because navigational freedom was "inhibited by restricted sea room and the existence of obstructions to navigation, such as present and future developments of large scale renewable energy (wind)." ${ }^{206}$ The proposals aimed at reducing the

198 Loyens \& Loeff, North Sea Offshore Wind: Developments in Belgium and The Netherlands, November 2014, p. 4, available online: <http://www.loyensloeff.com/nl-NL/Documents/NorthSeaoffshorewind.pdf>. In March 2015 the Offshore Wind Energy Act (Wet windenergie op zee) setting out a tendering process for OWF development in sites yet to be established was legislated and is expected to enter into force in July.

${ }^{199}$ General introduction to the proposals for new and amended routeing measures off the Coast of the Netherlands between Texel and North Hinder, Submitted by The Netherlands, IMO Doc. NAV 58/3/2, 28 March 2012 [hereafter cited as “IMO Doc. NAV 58/3/2"], p. 2. The multiple marine uses include shipping, fishing, oil and gas activities, offshore renewable energy, submarine cables and pipelines, military use areas, recreational uses, marine conservation, sand extraction, land reclamation and coastal protection works.

${ }^{200}$ For a discussion of early Dutch practices, see H. van Hoorn, G. Peet \& K. Wieriks, "Harmonizing North Sea Policy in The Netherlands," 9 Marine Policy (1985): 53-61.

${ }^{201}$ IMO Doc. NAV 58/3/2, see n. 199 above, p. 2.

${ }^{202}$ North Sea Routes FSA, see n. 195 above, p. 9.

${ }^{203}$ Small vessels navigating between the turbines raise particular safety issues, such as difficulty in identifying their precise position in a search and rescue scenario, detecting them when exiting into major shipping lanes and their reducing sea room for other vessels when navigation along the margins of farms. Id., p. 36.

${ }^{204}$ Id.

205 NAV 58/3/2 to NAV 58/3/10

${ }^{206}$ IMO Doc. NAV 58/3/2, see n. 199 above, p. 1. 
danger of collisions and allisions and thereby also protected the marine environment. The routeing measures included adjustments to existing traffic separation schemes, new traffic schemes, adjustment to a deep water route, establishment of emergency turning areas, realignment of precautionary areas, removal of an area to be avoided and creation of new such areas, and extension of an inshore traffic zone. ${ }^{207}$

Given the geographical constraints of the Dutch North Sea sector, the measures necessitated consultations with neighbouring States as the measures affected international routes cutting across the maritime zones of several neighbours. In particular, Belgium had interests in the boundary areas and as a result three submissions proposing amendments to routeing measures other than traffic separation schemes were jointly submitted by the two States. ${ }^{208}$ The United Kingdom was also consulted regarding the North Hinder area, but did not co-sponsor a submission for amendments to the traffic separation schemes. ${ }^{209}$ Subsequently, a Dutch submission regarding Off Friesland proposed a routeing measure to take into consideration a gas discovery and the need to align with neighbouring windfarms in the German sector. ${ }^{210}$

Particular routeing measures may be needed during the construction phase. With a short coastline and heavy commercial and recreational traffic in the territorial sea adjacent to The Netherlands, Belgium is able to locate OWFs only beyond the territorial sea. The establishment of OWFs on Thornton and Bligh Banks in the northeast of its EEZ necessitated an area to be avoided. ${ }^{211}$ The Thornton farm had 54 turbines and Bligh 55 turbines, aiming at a total $10 \%$ of the country's energy production by 2020 . With the construction process expected to take years, Belgium was wary in its proposal in indicating that restrictions to navigation would be temporary during the construction process, which included artificial islands and installations, and that was expected to take years. Thus its proposal would restrict traffic only during construction so that navigation would not be hampered unnecessarily in the meantime. With construction, only vessels associated with the construction, maintenance and cable laying activities would be permitted in the identified areas and guard vessels would be onsite to warn surface navigation. The restrictions would not apply to particular categories of vessels, such as warships, other government-owned ships on non-commercial service, scientific research vessels (with prior permission of the OWF operator) and vessels in distress or in force majeure situations. ${ }^{212}$

The United Kingdom made similar submissions to the IMO to adjust routeing measures as a result of OWF construction, namely the Greater Gabbard windfarm along the Sunk traffic

\footnotetext{
${ }^{207}$ Id., pp. 4-6.

${ }^{208}$ Id., p. 3. Amendments to routeing measures other than traffic separation schemes "In the approaches to Hook of Holland and at North Hinder" (NAV 58/3/9), Amendments to the traffic separation schemes "In the Approaches to Hook of Holland and at North Hinder" (NAV 58/3/8) and Amendments to the "Deep-water route leading to Europoort" (NAV 58/3/10).

${ }^{209}$ IMO Doc. NAV 58/3/2, see n. 199 above, p. 3.

${ }^{210}$ Report on the formal safety assessment (FSA) related to the proposed amendments in the routeing system "Off Friesland", IMO Doc. NCSR 1/INF.4, 27 March 2014.

${ }^{211}$ Belgium ATBA Submission, see n. 94 above.

212 Id.
} 
separation scheme in the Thames Estuary. ${ }^{213}$ Navigation safety needed to be improved as a result of limited sea room and obstructions to navigation, especially in converging areas. The farm contained 140 turbines (with a capacity of 504MW) and a further 140 (adding another 500MW) were planned. ${ }^{214}$ The recently operationalised 160 turbine Gwynt y Môr OWF off the coast of Wales also required a traffic separation scheme in Liverpool Bay. The scheme provided for organised and safe crossing traffic during the construction and operation of the OWF. ${ }^{215}$

As a general observation, the States involved in the submissions to the IMO discussed above were particularly respectful of international navigation rights and the IMO procedures, perhaps not only because of the perceived treaty obligations of coastal States, but also because they are traditionally maritime states with a deep-seated interest in the free flow of maritime trade. Resorting to the IMO served the critical function of legitimizing their marine spatial management practices and sending a message to others. Their practice serves to strengthen the expectation of how other States in similar situations should proceed in the future, rather than acting on a unilateral basis outside the IMO framework.

\section{CONCLUSION}

Offshore wind farms create an unparalleled use of the world's ocean spaces in terms of the number, scale and area of these developments. The proliferation of OWFs creates a heightened potential for conflicts with other marine users. Moreover, they have the potential of fundamentally changing the operating environment of a wide variety of marine users, including the traditional uses of shipping, fishing, offshore oil and gas, cable-laying, recreational boaters and others. In some respects, the conflict between the rights of coastal States to use their maritime zones to develop OWF capacity and the rights of other marine users is reminiscent of the longstanding tension animating the negotiations which culminated in the LOS Convention - the tension between coastal State rights and international navigation rights. The international law of the sea and international maritime law perform a vital service in managing that tension through a practical and pragmatic procedure to achieve mutual accommodation of functional interactions between offshore renewable energy development and international navigation rights of multiple users.

This article underscores how that vital service is achieved, and particularly in three ways. The first concerns the relationship between the international law of the sea and international maritime law. While the LOS Convention provides a constitutional framework for the exercise of jurisdiction over ocean space and its users, the international maritime conventions and instruments under the auspices of the IMO serve to guide and nourish the exercise of jurisdiction. Second, the role allocated to the IMO and the high regard with which it is held in the maritime world, facilitate

\footnotetext{
${ }^{213}$ For a discussion of the policy and legal issues concerning the establishment of OWFs in the United Kingdom, see: G. Plant, "Offshore Renewable Energy Development in the British Islands: Legal and Political Risk," Renewable Energy Law and Policy Review 4, 3 (2013): 189-228; G. Wright, "Regulating Marine Renewable Energy Development: A Preliminary Assessment of UK Permitting Processes," Underwater Technology 32 (2014): 39-50.

${ }^{214}$ Amendments to the Traffic Separation Scheme "Sunk TSS East" Submitted by the United Kingdom, IMO Doc. NAV 57/3/9, 5 April 2011.

${ }^{215}$ Establishment of a new Traffic Separation Scheme in "Liverpool Bay”, IMO Doc. NAV 54/3/9, 25 April 2008.
} 
the administration of the relationship between the law of the sea and maritime law. This is achieved through the Organization's function in the development of international rules and standards, and the procedural mechanisms and guidelines developed to operationalize rules. The effect is to help manage tensions between competing ocean uses through a technical "peer review" process of submissions for routeing measures and community legitimization of approved measures. Third, the acquisition of internationally sanctioned measures significantly strengthens the efforts of national marine spatial planners when treading on sensitive issues, in particular where a generally recognized international route is affected and ocean space needs to be re-allocated. The service is in effect a systemic response to the challenges posed by offshore renewable energy development.

The system appears to function well at this time, particularly considering that the scale at which OWFs could be established and function was not fully anticipated by the negotiators of the LOS Convention. The Convention was negotiated at a high level of generality to enable its interpretation and application to new situations. This article highlighted significant interpretational issues in the event that OWFs are located on the continental shelf beyond 200M, in particular with regards to coastal State rights and responsibilities where high seas user States are of the view that the freedom of the high seas on the outer continental shelf includes offshore energy production. The international law of the sea and international maritime law have never been static. On the contrary, they have been responsive (perhaps more in hindsight than in anticipation) to technological, commercial and environmental forces, and most especially through the vehicle of State practice. State practice in offshore renewable energy can be expected to assist further development of the law. 


\section{ANNEX}

The balance between coastal State rights relevant for OWFs and international navigation and other rights in national maritime zones (LOS Convention provisions in square brackets)

\begin{tabular}{|c|c|c|c|}
\hline Zone & Coastal State jurisdiction & International rights & Regulatory consequences for $\mathrm{OWF}$ \\
\hline Internal waters & $\begin{array}{l}\text { - Covers seabed, subsoil, water } \\
\text { column \& airspace } \\
\text { - Sovereignty [2] }\end{array}$ & $\begin{array}{l}\text { - No general international right of } \\
\text { navigation } \\
\text { - Innocent passage where former } \\
\text { high seas are now enclosed as } \\
\text { internal waters [8(2)]; } \\
\text { - Customary right to refuge }\end{array}$ & $\begin{array}{l}\text { - } \\
\text { - International navigation rules \& standards applied at } \\
\text { discretion of coastal State } \\
\text { - } \quad \text { Port State regimes apply } \\
\text { - Customary humanitarian duty to provide refuge to } \\
\text { vessels in distress or force majeure }\end{array}$ \\
\hline $\begin{array}{l}\text { Archipelagic } \\
\text { waters }\end{array}$ & $\begin{array}{l}\text { - Covers seabed, subsoil, water } \\
\text { column \& airspace } \\
\text { - Sovereignty [49] } \\
\text { May suspend temporarily innocent } \\
\text { passage/archipelagic sea lanes } \\
\text { passage [52(2)] } \\
\text { May designate sea lanes \& air routes } \\
\text { for archipelagic sea lanes passage } \\
\text { [53] }\end{array}$ & $\begin{array}{l}\text { - Innocent passage [52(1)] } \\
\text { Archipelagic sea lanes passage } \\
\text { when sea lanes established [52(1), } \\
\text { 53] } \\
\text { Existing international cables not } \\
\text { making land fall to be respected } \\
\text { [51(2)] }\end{array}$ & $\begin{array}{l}\text { - National regulation } \\
\text { - International navigation rules \& standards apply } \\
{[21(4)]} \\
\text { - Archipelagic State to permit maintenance \& } \\
\text { replacement of cables on the basis of notice [51(2)] }\end{array}$ \\
\hline $\begin{array}{l}\text { Territorial sea } \\
(12 \mathrm{M})\end{array}$ & $\begin{array}{l}\text { - Covers seabed, subsoil, water } \\
\text { column \& air space } \\
\text { - Sovereignty, including straits used } \\
\text { for international navigation [2] } \\
\text { - Right to establish TSS [22] } \\
\text { May suspend innocent passage } \\
\text { when essential for security [25(3)] } \\
\text { Right to establish conditions for } \\
\text { cables \& pipelines entering territory } \\
\text { \& territorial sea [79(4)] }\end{array}$ & $\begin{array}{ll}\text { - } & \text { TS: innocent passage }[47,19] \\
\text { - } & \text { Straits (1): transit passage in straits } \\
& {[38]} \\
\text { - } & \text { Straits (2): innocent passage [Art. } \\
& 45] \\
\text { - } & \text { Distress exception to innocent \& } \\
& \text { transit passage }[18(20), 39(1)(3)]\end{array}$ & $\begin{array}{ll}\text { - } & \text { National laws \& regulations apply }[21,42] \\
\text { - } & \text { International navigation rules \& standards apply } \\
\text { - } & \text { Re TSS, to take into account IMO recommendations } \\
\text { - } & \text { Must not hamper international navigation }[24(1)] \\
\text { - } & \text { Must not discriminate or hamper transit through straits } \\
& {[42(2), 44]}\end{array}$ \\
\hline$E E Z(200 M)$ & $\begin{array}{l}\text { - Covers seabed, subsoil \& water } \\
\text { column }\end{array}$ & $\begin{array}{l}\text { - Freedoms of navigation, overflight } \\
{[58(1)]}\end{array}$ & $\begin{array}{l}\text { - National regulation applies limited to EEZ powers } \\
\text { - AIIS [60]: } \\
\text { ○ Due notice of AIIS construction requirement }\end{array}$ \\
\hline
\end{tabular}




\begin{tabular}{|c|c|c|c|}
\hline & $\begin{array}{l}\text { - Sovereign rights over natural } \\
\text { resources \& to explore and exploit } \\
\text { wind energy [56(1)(a)] } \\
\text { Rights re seabed \& subsoil to be } \\
\text { exercise according to Part VI } \\
\text { (continental shelf)[56(3)] } \\
\text { Jurisdiction re establishment \& use } \\
\text { of AIIS [56(1)(b)(i)] } \\
\text { Exclusive right to construct, } \\
\text { authorize \& regulate construction, } \\
\text { operation \& use of AISS for wind } \\
\text { energy and installations \& } \\
\text { structures that interfere with the } \\
\text { exercise of its rights [60(1)] } \\
\text { Exclusive jurisdiction, including for } \\
\text { customs, fiscal, health, safety \& } \\
\text { immigration [60(2)] }\end{array}$ & $\begin{array}{l}\text { - Submarine cables \& pipelines } \\
\text { - } 58(1)] \\
\text { Other internationally lawful ocean } \\
\text { uses related to these freedoms } \\
\text { compatible with LOS Convention } \\
{[58]}\end{array}$ & $\begin{array}{l}\text { Abandoned or disused installations \& structures to } \\
\text { be removed taking into account international } \\
\text { standards; to take account of other uses; to be } \\
\text { publicized if not fully removed } \\
\text { Reasonable safety zones for safety of navigation } \\
\text { and islands, installations \& structures; up to } 500 \\
\text { metres, unless authorized by generally accepted } \\
\text { international standards or as authorised by IMO } \\
\circ \quad \text { Due notice of safety zones } \\
\text { AIIS may not be established where they interfere } \\
\text { with international navigation } \\
\text { All ships to respect safety zones \& to comply with } \\
\text { international standards } \\
\text { International navigation rules \& standards apply }\end{array}$ \\
\hline $\begin{array}{l}\text { Continental } \\
\text { shelf: } \\
\text { (a) Inner } \\
\text { shelf: } \\
\text { limit of } \\
200 \mathrm{M} \\
\text { (b) Extended } \\
\text { shelf: } \\
\text { limit of } \\
350 \mathrm{M} \text { or } \\
100 \mathrm{M} \\
\text { from } \\
2,500 \mathrm{~m} \\
\text { isobath }\end{array}$ & \begin{tabular}{|l} 
- \\
- \\
Exclusive \\
living \& sovereign rights over \\
resources, including (mineral) \\
species [77] \\
Exclusive right to authorize and \\
regulate drilling [81]
\end{tabular} & $\begin{array}{ll}\text { - } & \text { Freedom of international } \\
& \text { navigation [78] } \\
\text { - } & \text { Submarine cables and pipelines } \\
\text { - } & \text { Ing(1)] } \\
\text { Installations and structures }\end{array}$ & $\begin{array}{l}\text { - National regulation applies limited to CS powers } \\
\text { - } \quad \text { AIIS rules in EEZ apply mutatis mutandis [80] } \\
\text { - } \quad \text { Activities of coastal State must not infringe or } \\
\text { unjustifiably interfere with navigation \& other } \\
\text { rights/freedoms [78(2)] } \\
\text { - International right to lay cables \& pipelines [79(1)]: } \\
\text { Coastal State may not impede laying, subject to } \\
\text { right to take reasonable measures for exploration } \\
\text { of CS \& exploitation of resources [79(2)] } \\
\text { Delineation of course subject to coastal State } \\
\text { consent [79(3)] } \\
\text { Rights of coastal State to establish conditions for } \\
\text { cables \& pipelines [79(4)] } \\
\text { Due regard to cables \& pipelines already in } \\
\text { position, including their repair [79(5)] }\end{array}$ \\
\hline High seas & - Flag State jurisdiction [94] & $\begin{array}{l}\text { - Freedom of international } \\
\text { navigation, overflight \& cables \& } \\
\text { pipelines }[87(1)(\mathrm{a},(\mathrm{b}),(\mathrm{c})]\end{array}$ & $\begin{array}{l}\text { - Freedoms subject to due regard duty }[87(2)] \\
\text { - Installations for activities in the Area subject to rules, } \\
\text { regulations \& procedures of ISA [147] } \\
\text { - International navigation rules \& standards apply }\end{array}$ \\
\hline
\end{tabular}




\begin{tabular}{|l|l|l|l|}
\hline & $\begin{array}{l}\text { Freedom of high seas for } \\
\text { installations \& structures not } \\
\text { related to activities in the Area }\end{array}$ & $\bullet$ Flag State duties [94] \\
\hline
\end{tabular}

